\title{
Cyclical Fiscal Rules for Oil-Exporting Countries
}

Stephen Snudden 


\title{
IMF Working Paper
}

Research Department

\section{Countercyclical Fiscal Rules for Oil Exporting Countries \\ Prepared by Stephen Snudden ${ }^{1}$}

Authorized for distribution by Benjamin Hunt

November 2013

\begin{abstract}
Structural budget-balance rules with countercyclical elements appear well suited to stabilize the macroeconomic volatility of oil-exporting countries and have been used successfully by other commodity exporters. Using a global DSGE model, the efficient design of such rules is found to depend on the source of oil price fluctuations and the oil exporters' structural characteristics. The output-inflation tradeoff is of particular concern for oil exporters relative to non-oil exporters due to the pass through of oil prices into headline inflation. Fiscal rules are best when coordinated with inflation targeting monetary policy, but are still desirable for fixed exchange rate regimes.
\end{abstract}

JEL Classification Numbers: E62, E63, F41, H62, Q43, Q48

Keywords: Fiscal policy rules; automatic stabilizers; countercyclical fiscal policy; macroeconomic policy; oil price.

Author's E-Mail Address: ssnudden@,imf.org

\section{This Working Paper should not be reported as representing the views of the IMF.}

The views expressed in this Working Paper are those of the author(s) and do not necessarily represent those of the IMF or IMF policy. Working Papers describe research in progress by the author(s) and are published to elicit comments and to further debate.

\footnotetext{
${ }^{1}$ The author thanks Gregor Smith for his advice and supervision. The author would also like to thank John Bluedorn, Rupa Duttagupta, and Andrea Pescatori for their key role in initiating this project and to Ben Hunt, Michael Kumhof, Douglas Laxton, Dirk Muir, Thomas Sargent, Natalia Tamirisa, Evan Tanner, Susan Yang and seminar participants at the International Monetary Fund for their insightful comments and suggestions.
} 


\section{Contents}

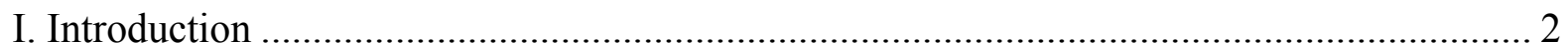

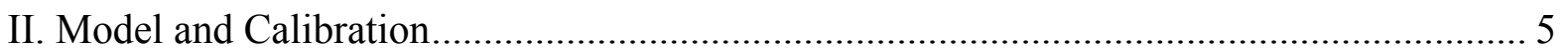

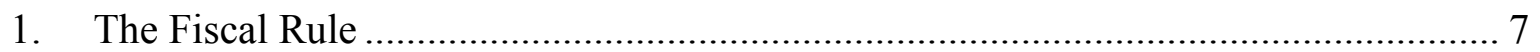

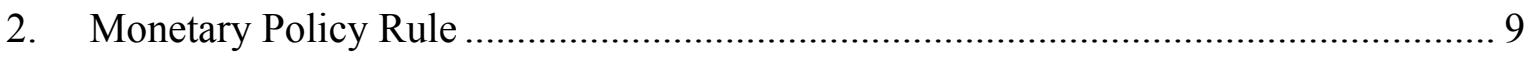

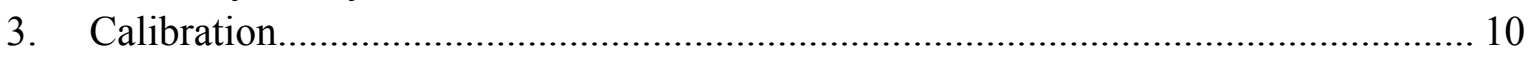

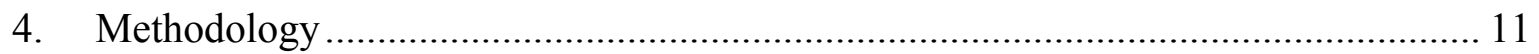

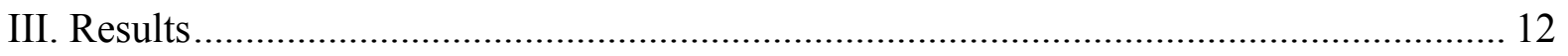

1. Temporary Demand and Supply Shocks to the Price of Oil .................................... 12

1.1 Efficient Fiscal Policy to Temporary Increases in the Price of Oil..................... 14

1.2 Inflation and Output Volatility Tradeoff....................................................... 15

2. Implications under Alternative Structural Characteristics .......................................... 17

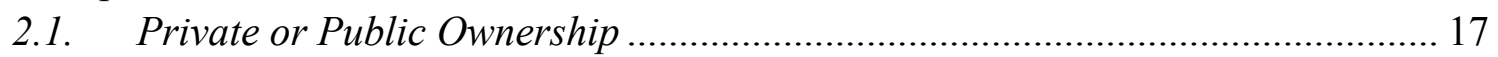

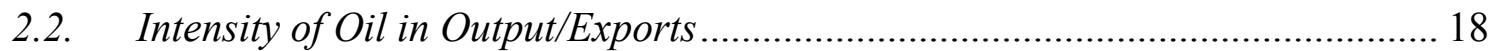

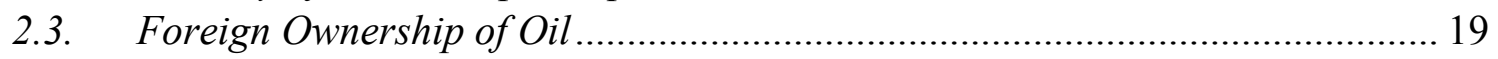

2.4. Composition of the Non-Oil Tax Revenues ....................................................... 19

2.5. Oil Intensity in the Consumption Basket ......................................................... 20

3. Implications under Alternative Policy Assumptions .................................................. 21

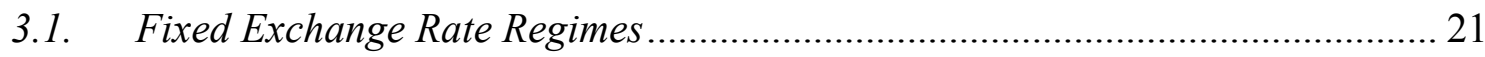

3.2. Joint Monetary Policy Considerations …………............................................ 22

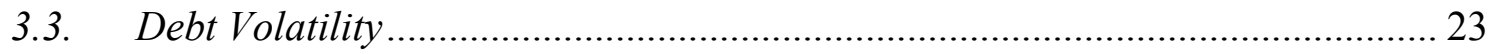

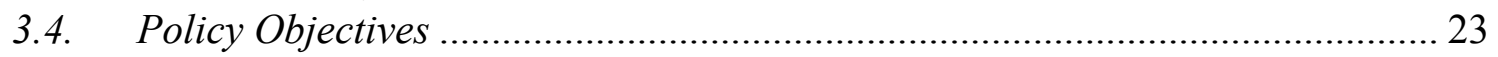

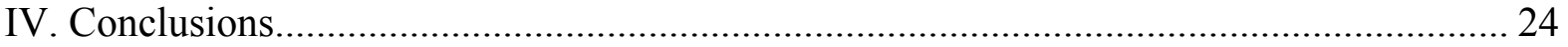

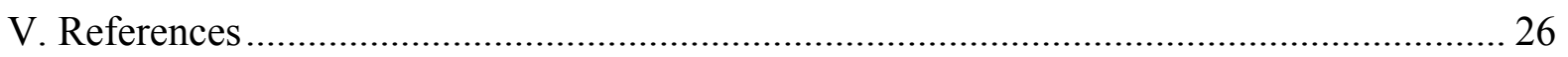

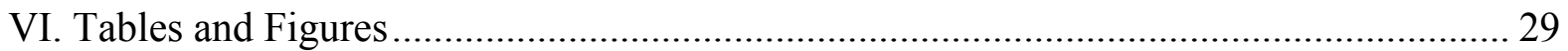

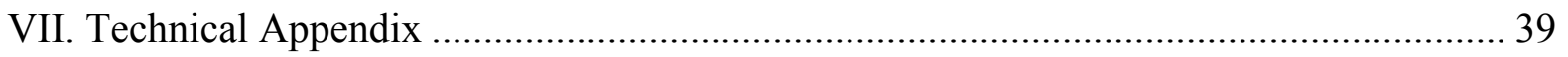

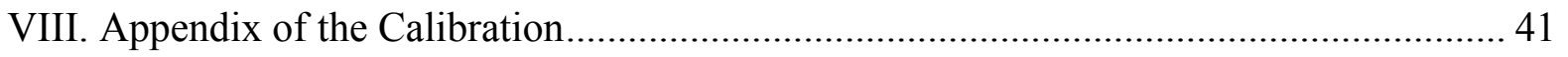




\section{INTRODUCTION}

The success of Chile's commodity-based fiscal rule has sparked interest in fiscal policy rules for business cycle stabilization in other commodity-exporting countries. This paper examines the appropriate design of cyclical fiscal policy rules for oil-exporting countries using the Global Integrated Monetary and Fiscal model (GIMF). GIMF is a global dynamic structural general equilibrium (DSGE) model and is calibrated with two regions: a small open oil exporter (SOE) and the rest of the world (ROW). The multiple layers of production and detailed international trade linkages allow for an examination of efficient policy to oil price fluctuations arising from multiple sources of external disturbances in the global market for crude oil.

Employing a structural-budget-balance rule with countercyclical elements appears well suited to stabilize the macroeconomic volatility of oil-exporting countries. The analysis suggests that the efficient fiscal policy rule for business cycle stabilization is countercyclical to oil and tax revenues. Further, the desired fiscal response depends on the source of the oil price fluctuation, the underlying structural characteristics of the commodity exporter, and the policy framework. Importantly, the situation for oil exporters is complicated by a tradeoff between inflation and output volatility due to higher oil content in the consumption basket. A structural-budget-balance rule with countercyclical elements is robust to various expenditure and taxations instruments satisfying the fiscal rule.

Several economists have argued that developing countries too often adopt procyclical macroeconomic policies that exacerbate macroeconomic volatility (Gavin and Perotti, 1997; Kaminsky and others, 2004; Talvi and Vegh, 2005; Kaminsky, 2010). Increasingly, empirical evidence suggests that the mismanagement of the commodity revenues may be a primary culprit behind the volatility in commodity-exporting countries (Adler and Sosa, 2011; Frankel and others, 2013). Commodity price fluctuations have implications for all macroeconomic and prudential policies, but fiscal policy is of primary importance due to state ownership of natural resources in oil-exporting countries (see Husain and others, 2008). 
Indeed, Husain and others (2008) find that oil price changes affect the economic cycle of oil exporters primarily through their impact on fiscal policy. ${ }^{2}$

The procyclicality of fiscal policy was particularly evident for the oil-price shocks of the 1970s and early 1980s. Recent evidence suggests reduced procyclicality during the oil price run up in the 2000s (Céspedes and Velasco, 2011). However, Medina (2010) notes stark differences across countries. For example, Venezuela has exhibited more procyclical policy, whereas Chile, with its explicit fiscal framework, has successfully reduced macroeconomic volatility to commodity price fluctuations. This had brought calls for the adoption of formal fiscal frameworks to manage the commodity revenue volatility (Kumhof and Laxton, 2010; Frankel and others, 2013).

Policy recommendations surrounding commodity price uncertainty and volatility have previously focused on reducing procyclicality by accumulating the variability of revenues into a sovereign wealth fund and targeting the non-oil balance (see Barnett and Ossowski, 2003; Davis and others, 2002). Although acycical fiscal policy may be preferred to procyclical fiscal policy, it is generally understood that policy should be countercyclical over the business cycle (Varangis and others, 1995; IMF, 2012). Indeed, recent research has begun to show that countercyclical fiscal rules are particularly effective at reducing macroeconomic volatility for commodity exporters (Kumhof and Laxton, 2010; Bi and Kumhof, 2011).

Kumhof and Laxton (2009a) find that an efficient countercyclical rule can increase welfare by around 50 percent relative to balanced budget rule when applied to the case of copper for Chile. They assert that this can be achieved with only small increases in fiscal instrument volatility when the appropriate fiscal instruments are utilized. When fiscal and monetary rules are jointly optimized for commodity exporters, Bi and Kumhof (2011) show that welfare gains from optimizing the fiscal rule are larger than from optimizing the

\footnotetext{
${ }^{2}$ Macroeconomic stabilization in the face of commodity price volatility is only one of many policy priorities for commodity-exporting developing and emerging economies. Others include resource exhaustibility, intergenerational equity, and Dutch disease challenges associated with resource discoveries. The relative priority of addressing various policy challenges depends on country-specific conditions. This paper contributes to the investigation of the policy framework for cyclical objectives, which should be combined with policies frameworks addressing longer-term objectives of commodity exporters. See Baunsgaard and others (2012), Berg and others (2013), Collier and Goderis (2007), Deaton and Laroque (1999), Eyzaguirre and others (2011), and Medas and Zakharova (2009) for a discussion of some of these issues.
} 
monetary rule in commodity-exporting economies due primarily to the larger share of nonRicardian agents.

Almost all of the current studies on the short-run management of revenues via fiscal policy rules focus on the case of managing copper revenues in models calibrated for Chile (Kumhof and Laxton 2009a; Bi and Kumhof, 2011; Garcia and others, 2011). However, in order to recommend the general use of fiscal policy rules, their appropriateness should be robustly tested for a wider range of commodity specializations, sources of price fluctuations, etc. This is especially applicable given the heterogeneity of oil exporter's structural characteristics, from diversified advanced countries such as Canada and Australia, to OPEC oil specialists such as Saudi Arabia.

The analysis of this paper confirms that for oil exporters it is generally preferable to employ a countercyclical response to non-oil tax revenue, consistent with Laxton and Kumhof (2009a), but also to follow a slight countercyclical response to changes in oil revenues. This is due to the pass-through of oil prices into the consumption basket which is highly correlated with oil revenues. The source of oil price fluctuations creates differing output-inflation tradeoffs. Responding countercyclically to external supply shocks can quickly cause output to fall in an effort to reduce inflation volatility. In contrast it is preferable to respond more countercyclically to broad-based external demand shocks due to the larger impact on the non-oil economy. In addition, the desired degree of countercyclicality is found to depend on the oil intensity in total output, the share of private and foreign ownership, and the intensity of oil in the consumption basket. In addition, fiscal rules are found to be best combined with core-inflation targeting monetary policy regimes, but are also desirable for fixed exchange rate regimes.

The paper is structured as follows: Section II outlines the structure and calibration of the model. Section III describes the results in three parts. The first part looks at the preferred fiscal policy rules for a benchmark oil exporter in the face of external oil-price shocks. This analysis is extended to various structural characteristics of oil exporters and their policy frameworks. Section V concludes. 


\section{Model ANd CAlibration}

This paper uses an annual version of the Global Integrated Monetary and Fiscal model (GIMF) calibrated with two regions: a small open oil exporter (SOE), and the rest of the world (ROW). The entire global economy is modeled which allows for structural shocks originating in the ROW to impact the SOE through a variety of channels including via the effect on the global market for crude oil, as well as from trade and financial linkages. Since the underlying structure of the model and its properties is described in detail elsewhere, this section provides an overview of the model structure and calibration with focus on the relevant aspects of the oil sector and fiscal policy. ${ }^{3}$

GIMF is a global dynamic structural general equilibrium model in wide use at the IMF. The model is micro-founded with optimizing behavior of both households and firms. There is intertemporal stock-flow accounting in the level of government debt, net foreign assets, human wealth, and capital stocks. Keynesian properties are derived from frictions in the form of real and nominal adjustment costs, and the presence of both liquidity-constrained agents and finite planning horizons of households. These Keynesian features provide nonneutrality in both spending- and revenue-based fiscal measures. They also capture the interaction of fiscal and monetary policies, which makes the model particularly suitable to analyze fiscal policy.

Households pay distortionary taxes on labor income and consumption spending, and a non-distortionary lump-sum tax. Liquidity-constrained households (LIQ) consume all of their income in every period. Overlapping-generation households (OLG) are unconstrained and smooth their consumption. ${ }^{4}$ The presence of OLG households means that public debt is counted as net wealth since there is a probability that associated tax liabilities will fall

\footnotetext{
${ }^{3}$ The theoretical micro-foundations of the model including the oil sector are described in detail in Kumhof and others (2010). A detailed examination of the GIMF properties can be found in Anderson and others (2013). The technical appendix describes the structure of the oil sector.

${ }^{4}$ See Blanchard (1985) for the basic theoretical building blocks.
} 
beyond their planning horizon. ${ }^{5}$ Thus, a decrease in government debt today represents a decrease in OLG household wealth.

Production in GIMF is multi-layered. Capital, labor, and oil produce intermediate tradable and non-tradable goods. Capital is supplied by entrepreneurs with a procyclical financial accelerator à la Bernanke and others (1999). Firms have finite planning horizons in accordance with the preferences of their owners, the OLG households. Firms pay capital income taxes to governments and wages and dividends to households. Physical capital is sector-specific, but labor is mobile across sectors. Neither labor nor physical capital is mobile across regions, although trade in investment goods eases the restrictiveness of this assumption.

Domestic and imported intermediate goods are combined to produce consumption and investment goods. A share of oil is consumed directly in the household's consumption basket. Thus, an increase in the price of oil drives up the cost of production as well as the cost of the final consumption basket. The demand for oil, in production as well as in the consumption basket, is highly inelastic. The supply of oil is produced from an exogenous endowment with a small long-run price elasticity of supply with a ten-year lag. Oil rents are the difference between the extraction cost and the market price of oil and may accrue to households, the government, or foreign households.

The multi-country structure of GIMF captures the effects of international trade spillovers. Bilateral trade flows of intermediate goods and final consumption and investment goods are modeled explicitly along with the relative prices between each region. Asset markets are incomplete, and the only assets traded internationally are nominal, noncontingent one-period bonds denominated in the rest of the world currency. Government debt is domestically owned and can crowd out the domestic holdings of net foreign assets. Firms are owned domestically and pay lump-sum dividends on a share of profits.

Real returns are equilibrated globally in the global savings and investment market by the global real interest rate. The SOE can borrow and save at the global real interest rate.

\footnotetext{
${ }^{5}$ For a more detailed description of wealth implications of fiscal policy in GIMF see Kumhof and Laxton (2009b).
} 
This assumes that the sovereign risk premium is not responsive to the level of net foreign assets.

\section{The Fiscal Rule}

The fiscal authority employs a generalized structural-surplus tax-gap rule with commodity revenues and general taxes added separately, a class of fiscal rules known as budget-balance rules. Kumhof and Laxton (2009a) motivate the use of such rules and find that they are welfare improving when compared to instrument rules, debt rules, or output gap rules due to their superior ability to align the adjustment of the fiscal related household income with the macroeconomic cycle. In particular, the tax bases underlying tax-revenue gaps provide the fiscal authority with a way to closely observe the adjustment of private incomes of households. The fiscal rule is summarized as follows:

$$
g s_{t}^{r a t}=g s^{r a t^{*}}+d^{t a x} \frac{\left(\tau_{t}-\tau_{t}^{s S}\right)}{g d p_{t}}+d^{o i l} \frac{\left(\tau o_{t}-\tau o_{t}^{s S}\right)}{g d p_{t}}+d^{d e b t}\left(\frac{b_{t}}{g d p_{t}}-\bar{b}^{r a t}\right)
$$

where $g s_{\mathrm{t}}^{\text {rat }}$ is the overall fiscal surplus-to-GDP ratio, $g s^{\text {rat }^{*}}$ is the overall fiscal surplus-toGDP ratio target, $\tau_{t}$ and $\tau o_{t}$ are the level of non-oil and oil revenues, $\tau_{t}^{S S}$ and $\tau o_{t}^{S S}$ are the steady-state level of non-oil and oil revenue, respectively. $b_{t}$ is the nominal level of net savings of the sovereign authorities and $\bar{b}^{\text {rat }}$ is the steady-state net savings to GDP ratio. The coefficient $d^{d e b t}$ is set to zero for most of the analysis and is explored in more detail in section III.3.3.

The rule has two main functions. The first is to stabilize the government debt-to-GDP ratio to its long-run target which is done by centering on the overall government surplus-toGDP ratio, $g s^{\text {rat }^{*}}$. This target pins down the long-run net asset position of the general government, and ensures dynamic stability. Notice that the rule does not require the debt feedback coefficient, $d^{\text {debt }}$, to be greater than zero, although this would return the debt level faster to steady state. By targeting the overall deficit, the long-run target is inclusive of the potential oil and tax revenues, similar to the rule employed in Chile.

The second main function of the fiscal rule is to respond to the business cycle. The rule allows the fiscal authority to adjust the overall surplus-to-GDP ratio, $g s_{t}^{r a t}$, to changes in the non-oil and oil tax-revenue gaps. The gaps are the difference between the actual revenues and the potential level of revenues which the fiscal authority knows with certainty. 
As summarized in Table 5, potential non-oil revenues are the sum of steady-state consumption, labor income, and capital income taxes multiplied by their respective tax bases. The steady-state levels of oil revenues are summarized in Table A.6.

This generalized form of the rule allows calibrations of $d^{\text {tax }}$ and $d^{\text {oil }}$ to determine the responsiveness of the surplus-to-GDP ratio to changes in the non-oil tax revenue and oilrevenue gaps. In practice, this represents a continuum of rules, of which there are three main categories.

- A balanced budget rule (BBR): A calibration of $d^{\text {tax }}$ and $d^{\text {oil }}$ equal to zero denotes a balanced budget rule. Under such a rule, the government budget is balanced in every period, so changes in oil and tax revenues are redistributed immediately to households through changes in tax rates or spending. This rule is procyclical by design but maintains the fiscal balance and net debt at their long-term targets.

- A structural-surplus rule (SSR): A calibration of $d^{\text {tax }}$ and $d^{\text {oil }}$ equal to one denotes a structural-surplus rule. Under this rule, changes in oil and tax revenues are saved (thereby avoiding any change in tax rates or spending). ${ }^{6}$ This rule results in a one-forone change in the overall fiscal balance in response to deviations of oil and tax revenues gaps. This rule is acyclical, since it does not add or subtract from aggregate demand.

- A countercyclical rule (CCR): A calibration of $d^{\text {tax }}$ and $d^{\text {oil }}$ greater than one denotes a countercyclical rule. Under this rule, the fiscal authority more than saves changes in oil and tax revenues. This rule implies larger changes in budget surpluses and government debt in response to oil price changes, and acts countercyclically, increasing (reducing) the structural balance during periods of strong (weak) oil prices and/or economic activity.

The rule is a generalized form of the class of budget-balance targeting rule and not an instrument rule. Thus, any fiscal instrument can adjust to satisfy the fiscal rule. Specifically, in each period, the fiscal authority determines the level of tax rates or spending to achieve the

\footnotetext{
${ }^{6}$ The overall fiscal balance is targeted, so the instrument satisfying the rule will still respond to changes in interest service costs.
} 
deficit targeted. In this paper, the baseline fiscal instrument that adjusts to satisfy the fiscal rule is the labor income tax. The labor tax rate is chosen for its conservative inflation and output multipliers and does not constitute a policy recommendation. ${ }^{7}$ Considerations regarding the use of alternative fiscal instruments are also examined.

The fiscal policy stance can be interpreted by the coefficients on the tax gaps and the change in the overall fiscal balance. Since the fiscal-rule coefficients respond to the tax gaps, the cyclical balance depends on both the size of the gap and the coefficient. Thus, in Table 10 and 12 , both the coefficients and the difference between the overall fiscal balance of the efficient fiscal policy rule and the SSR as a percent of GDP are reported. In this paper, the aggressiveness of the fiscal balances is the difference between the overall deficit-to-GDP ratio of the CCR relative to the SSR.

Over the past two decades, there has been an increase in the adoption of rules-based fiscal policy (Céspedes and Velasco, 2011; and IMF, 2009; Schaechter and others, 2012). In practice, fiscal policy behavior in a number of commodity exporters has been broadly influenced by rules of this kind. Chile follows a structural-surplus rule, which allows for the presence of automatic stabilizers. Norway's rule targets a structural non-oil balance and also allows for the possibility of countercyclical responses over the business cycle.

\section{Monetary Policy Rule}

The central bank credibly operates under an inflation targeting regime with a Taylortype interest rate reaction function. The policy rate, $i_{t}$, responds to the three-quarter-ahead gap between projected core inflation, $\tilde{\pi}_{t}$, and target inflation, $\bar{\pi}_{t}$, to achieve a stable target rate of inflation. ${ }^{8}$ The target rate is assumed to be 2 percent in both the SOE and the rest of the world regions. The monetary policy function is defined as follows:

$$
1+i_{t}=E_{t}\left(1+i_{t-1}\right)^{\delta_{t}}\left(\left(1+r_{t}^{e q}\right)\left(1+\tilde{\pi}_{t}\right)\right)^{1-\delta_{t}}\left(\frac{1+\widetilde{\pi}_{t}}{1+\bar{\pi}_{t}}\right)^{\left(1-\delta_{t}\right) \delta_{\pi}}
$$

\footnotetext{
${ }^{7}$ In GIMF, the labor income tax rate is distortionary, and broadly corresponds to payroll taxes, regardless of whether they are levied on employees or employers, and personal income taxes.

${ }^{8}$ The targeting of core inflation is understood to be best practice when monetary policy faces oil-price shocks. See Hogan and others (2001), and Natal (2009), Coletti and others (2012). Bi and Kumhof (2011) show that when monetary and fiscal policies are jointly optimized for commodity exporters the "optimized monetary rule features super-inertia and a very low coefficient on inflation." This is considered in section III.3.2.
} 
where $\left(1+r_{t}^{e q}\right)\left(1+\tilde{\pi}_{t}\right)$ is the gross nominal interest rate. The equilibrium real world interest rate $r_{t}^{e q}$ is a geometric moving average of the risk-adjusted global real equilibrium interest rate. The coefficient on the gap of projected core inflation and target inflation, $\delta_{\bar{\pi}}$, is calibrated to 1.5 , with a lag coefficient, $\delta_{t}$, of 0.3 . This calibration closely replicates the estimated inflation dynamics for a wide variety of shocks at annual frequency for Latin American countries in the IMF's Global Projection Model, see Canales-Kriljenko and others (2009). Although the level of the inflation target affects the steady-state model, the dynamic properties are little affected and the results are robust to alternative calibrations.

\section{Calibration}

The comprehensive structure of GIMF is reflected in the ability to replicate the key aspects of the SOE. In the initial simulations the model is calibrated to the average of 35 small, open, oil-exporting countries for which data is available and which oil exports represent over 10 percent of total exports. Later in the paper, sensitivity analysis is conducted around the baseline calibration. A complete catalogue of the calibration is presented in Tables 1 to 9 .

The steady-state national account decompositions are roughly calibrated to match recent years from the IMF International Financial Statistics database. The net government debt ratio is calibrated to 30 percent of GDP. Private consumption and investment expenditures are 60 and 20 percent of GDP, respectively. Trade openness, exports, and imports as a percent of GDP are calibrated to 40 percent of GDP.

The SOE is normalized to one percent of global real GDP. Net oil exports-to-GDP are calibrated to 18 percent of GDP. The share of oil consumed domestically is 6.5 percent of GDP. This represents the 4 percent of the consumption basket of households with the remainder used as an input into intermediate goods production. The SOE constitutes a small share of total global oil demand, which implies that domestic demand activity has almost no effect on the real global price of oil.

The resource cost of oil production is 40 percent of the value of oil produced. In the baseline simulations, oil production is domestically owned with no share of foreign ownership. The degree of public ownership of oil production is calibrated to the mid-range of 
estimates in Duttagupta and others (2012), with 75 percent of rents accruing to the government and the remaining 25 percent to households. The long-term price elasticity of oil demand in both production and consumption is 0.08 , while the short-term elasticity is $0.02 .{ }^{9}$ The endowment of oil has a low long-run price elasticity of supply, 0.03 , and responds fully only with a ten-year lag.

The calibration of the structural parameters relies heavily on the literature as summarized in Kumhof and others (2010) and Anderson and others (2012) as well as on the previous work on modeling SOEs in GIMF (Kumhof and Laxton, 2010). This includes the trade elasticities, as well as nominal and real rigidities, which are set to match the dynamics to models of SOEs at use in the IMF, summarized in Tables 2 and 9. The share of liquidityconstrained agents in the SOE is calibrated to 50 percent of households. This implies a moderate degree of responsiveness of aggregate consumption with respect to the total income of households.

\section{Methodology}

This paper focuses on temporary oil price fluctuations in a non-stochastic environment, and the assumption is that the fiscal authority identifies the shocks precisely. A loss function is evaluated over a set of parameterizations of the fiscal rule. Specifically, the fiscal authority seeks to minimize macroeconomic volatility which is defined as a weighted average of the standard deviation of the output gap and headline inflation from its target. The minimized loss function is searched over a grid of parameterizations of $\mathrm{d}^{\text {tax }}$ and $\mathrm{d}^{\mathrm{oil}}$. Calibrations of $\mathrm{d}^{\text {tax }}$ are searched up to 5, consistent with Bi and Kumhof (2011). Note that if $\mathrm{d}^{\text {tax }}$ was allowed to approach infinity, the non-oil tax revenue gap approaches zero. In practice this would imply an unrealistic degree of precision of the fiscal authority, hence the limitation.

The following loss function is evaluated for each parameterization of the fiscal rule:

$$
\text { Loss Function }=s d\left(\pi^{g a p}\right)+\lambda_{Y} * s d\left(g d p^{g a p}\right)
$$

\footnotetext{
${ }^{9}$ This is consistent with the calibration of GIMF used in the IMF World Economic Outlook, Chapter 4, April 2011.
} 
where $s d\left(\pi^{g a p}\right)$ is the standard deviation of actual headline inflation from the two percent inflation target, and $s d\left(g d p^{g a p}\right)$, is the standard deviation of real GDP from the steady-state level. The baseline focus on equal stabilization of the headline inflation and the output gap, $\lambda_{Y}$ calibrated to one, is consistent with the broad objective of business cycle stabilization for policy makers. Examinations of alternative specifications of the loss function are considered, including variations in the weight on the output gap, as well as for an examination on household welfare in section III.3.4.

In practice, it is difficult to distinguish between demand and supply factors as well as temporary and permanent oil price changes. A permanent oil price increase will have a permanent effect on potential revenues and the focus shifts to how to use these revenues most efficiently to maximize potential output and overall welfare. An avenue of further research could be operationalizing this rule in a stochastic environment with uncertainly.

\section{ReSUlts}

The preferred fiscal policy rule is searched for different sources of temporary oil price fluctuations on a generic SOE. Specifically, the analysis considers two cases: when the SOE is faced with an external demand-driven oil price increase and an external supply-driven oil price increase. The tradeoffs between output and inflation volatility are also explored. The analysis is complimented with an evaluation of efficient fiscal rules under alternative structural characteristics that differ across oil exporters. Under all cases, a countercyclical rule is found to be desirable; however, the gains from adopting the efficient fiscal rule and the desired degree of countercyclicality differ depending on the source of the shock and the SOE's structural and policy characteristics.

\section{Temporary Demand and Supply Shocks to the Price of Oil}

This section examines the desired fiscal rule for both demand and supply shocks for a 'baseline' calibration of the SOE. This calibration assumes that (i) oil production is owned almost wholly by the government, which receives 75 percent of the associated rent (through "oil revenues"); (ii) oil constitutes a large share of overall production, 19 percent of GDP, and 45 percent of exports; and (iii) there is no foreign ownership in domestic oil production. In practice, this is more representative of countries such as Algeria, Azerbaijan, Kazakhstan, Kuwait, Syria, and Venezuela. 
Two sources of external oil price fluctuations are explored. In the first scenario, the oil price increases in response to an unexpected increase in external economic activity. In the second scenario, the increase is due to an unexpected decline in the external supply of oil. In both scenarios, the shocks are calibrated so that they result in a 20 percent increase in the price of oil. In addition, the price of oil increases for 3 years, consistent with empirical findings of the average persistence of oil price fluctuations in Duttagupta and others (2012). Also consistent with those findings, the two sources of fluctuations have different effects on the SOE.

External supply-driven oil price increase. Under this scenario, a temporary decline in the external supply of oil increases the real price of oil by 20 percent in the first year, gradually returning over the next two years, as in Figure 1. As the rest of the world's GDP declines, so does the real external demand for all goods exported by the SOE. However, the fall in external demand is offset by the increase in the real value of the SOE's oil exports, thereby improving the trade balance, as in Figure 2. Despite the increase in headline inflation from higher oil prices, depressed global demand moderates the real price of final goods.

External demand-driven oil price increase. Under this scenario, a temporary increase in liquidity in the rest of the world boosts global demand all goods, as shown in Figure 3. The increase in foreign liquidity is generated by an exogenous temporary reduction in the spread between the nominal economy-wide rate and the monetary policy rate. As the cost of borrowing declines, credit expands as agents borrow to finance a boom in consumption and investment. There is a fall in net savings, and the real exchange rate depreciates in the ROW. A downturn follows the boom as agents deleverage and increase their saving back to initial levels. The higher demand drives up the real price of oil by about 20 percent in the first three years, after which oil prices decline and experience a boom-bust cycle. Contrary to a supplydriven oil-price shock, the global demand boom increases the demand and prices of all of the SOE's exports. Overall, the SOE experiences higher inflation and output volatility than under a case of a relative price increase in oil from a reduction in external oil supply, as shown in Figure 4. 


\subsection{Efficient Fiscal Policy to Temporary Increases in the Price of Oil}

For both the external supply- and demand-driven oil-price shocks, a countercyclical rule to both the oil and non-oil revenues gaps constitutes the efficient fiscal response. In the simulations, the need for countercyclical responses to the oil revenues is small. This largely reflects the baseline assumption that most of the oil rents accrue to the government, which in turn implies that insulating the economy from changes in government oil revenues is broadly sufficient for stabilization.

Figures 5 and 6 plot the evaluated loss function for alternative calibrations of the fiscal rule with a weight of 1 on the output gap, $\lambda_{Y}$. The efficient response of the fiscal authority for both types of shocks is to respond aggressively to the change in the tax revenues ( $d^{\operatorname{tax}}$, equal to 5). The tax-revenue gap is endogenous to the labor tax rate so the more aggressively the fiscal authority responds, the less of a tax-revenue gap is realized. Since the labor tax rate is distortionary, the non-oil revenues gap approaches zero as the parameter,

$d^{t a x}$, approaches infinity, without the risk of overshooting. For almost all cases considered, $d^{\text {tax }}$ is found to be the upper limit of the search: 5 .

In the case of the external supply shock, households' income from non-oil goods production falls, so there is little to increase demand once oil revenues are taken away. Thus, both output and inflation return very close to baseline under a SSR, and the efficient response is to save slightly more than the additional oil revenues ( $d^{\text {oil }}$ equal to 1.2). For the external oil supply shock, the price of consumption goods begins to fall once oil revenues are removed due to the fall in external demand. This causes core inflation to fall, easing monetary policy. Thus, fiscal policy is not as effective due to an unaccommodative monetary stance and must be slightly more countercyclical. Overall, the difference in the overall fiscal balance between the CCR and the SSR is 0.39 percent of GDP.

In contrast, an external demand shock increases the demand for all goods. In this case, even with no change in labor taxes, households still experience an increase in their income. Thus, a CCR can have larger gains over a SSR for a demand shock driving the price of oil, and monetary policy remains complementary with the fiscal rule. The efficient policy for a demand-driven increase in the price of oil is to more than save the additional oil 
revenues ( $d^{\text {oil }}$ equal to 1.1). Overall the difference in the fiscal balance of the efficient rule less the SSR is 0.45 percent of GDP.

Kumhof and Laxton (2009a) consider an external commodity-specific demand shock, while a broad-based external demand shock is considered in this paper. A commodityspecific demand shock increases the price of oil but results in a decline in demand for other commodities. In contrast a broad-based external demand-driven shock also increases the demand for non-oil commodities. Hence, the oil exporter responds countercyclically to the oil-revenues gap since a non-oil driven boom remains even once oil revenues are removed.

\subsection{Inflation and Output Volatility Tradeoff}

The inflation-output tradeoff is illustrated by the policy efficiency frontiers which are traced by varying the weight on the output gap in the loss function, $\lambda_{Y}$, as shown in Figures 5.A and 6.A. When oil price volatility is supply-driven, output falls quickly once oil revenues are removed so further reductions in inflation volatility come at the expense of additional output losses. In contrast, for the case of external demand-driven volatility, since output is increasing due to the effect on the non-oil balance, reductions in inflation volatility can be achieved with less risk of output falling.

This parallels the finding in the efficient monetary policy literature. In particular, Coletti and others (2012) find that the efficient response of both inflation and price-level targeting to external oil-price shocks is muted due to the inability of the small open economy to directly affect oil prices, which is the underlying cause of the increase in headline inflation. In an effort to reduce inflation volatility, an aggressive policy can cause large fluctuations in output. However, the use of fiscal policy can provide more flexibility to tackle the inflation-output tradeoff. In particular, fiscal policy has a larger selection of policy instruments with different fiscal output and inflation multipliers.

A desirable countercyclical instrument would achieve the desired impact on output and inflation with the smallest possible volatility in fiscal instruments. ${ }^{10}$ Instruments that directly affect LIQ households' income tend to achieve the largest inflation to output

\footnotetext{
${ }^{10}$ The choice of a countercyclical instrument should also take into account inequality and distortionary issues which are beyond the scope of this paper. Many developing economies do not rely as heavily on labor or consumption taxes which may make them infeasible.
} 
response due to LIQ households' inability to smooth consumption from income fluctuations, as shown in Table 2. ${ }^{11}$ An increase in the labor tax rate results in overall inflation and output movements of approximately similar magnitude, a multiplier of 0.25 . The use of expenditure-based instruments has the largest impact on output relative to inflation. Hence the gains from adopting a SSR relative to a BBR are largest. However, the benefits and costs from the use of expenditure instruments to satisfy a countercyclical response would depend on the goods purchased and their complimentary with private consumption and capital which is beyond the scope of this paper. However, when the baseline calibration is reanalyzed with general transfers satisfying the fiscal rule, since general transfers have a slightly smaller multiplier than labor taxes, a larger reduction in the deficit is required to induce a similar output and inflation response, see Table 12.

The automatic stabilizers in advanced countries primarily constitute the savings of the cyclical tax revenues, see Girouard and André (2005), which is achieved by following the SSR. In addition, many countries utilize additional forms of automatic stabilizers such as unemployment insurance. These are desirable to achieve a countercyclical response since they target households who have a high marginal propensity to consume. ${ }^{12}$ However, the efficient response of the fiscal balance would require adjustment beyond that often associated with unemployment regimes: changes in tax revenues of approximately 0.3 percent of GDP for a 20 percent increase in the price of oil. This may make sole use on just one automatic stabilization regime infeasible. Thus, it may be required to implement additional automatic stabilizers, to make up the difference with changes in taxes or spending.

Overall, the baseline simulations suggest that major reductions in volatility can be achieved by simply saving changes in tax revenues. Further reductions in output and inflation volatility can be realized by implementing additional automatic stabilization regimes. The use of formal CCR rules can discipline fiscal policy to achieve much more efficient outcomes.

\footnotetext{
${ }^{11}$ The short-term impact on the macroeconomy from fiscal instruments in GIMF is consistent with other structural models as documented in Coenen and others (2012).

${ }^{12}$ It should be noted that business cycle stabilization is only one of the motives for implementing unemployment benefit regimes and is probably not the most important. In addition, these policies may require a positive amount of spending in steady state, the cost of which would need to be compared to the benefit of business-cycle stabilization.
} 


\section{Implications under Alternative Structural Characteristics}

This section considers structural characteristics that differ across oil exporters and examines how this impacts the design of the efficient fiscal rule. In particular, five characteristics are considered: (i) when oil is largely domestically privately owned; (ii) when oil constitutes a different share of overall production; (iii) when oil constitutes a different share in the consumption basket; (iv) when there is a high degree of foreign ownership of production; and (v) when there are different non-oil tax bases. Under all cases, a countercyclical rule is still found to be desirable; however, the gains from adopting the efficient fiscal rule and the degree of countercyclicality differ depending on the economies structural characteristics, as shown in Table 1.

\subsection{Private or Public Ownership}

Efficient fiscal policy responds more to the tax-revenue gaps when faced with external oil-price shocks in an economy where oil is produced and rents accrue to private companies. To explore the case of private ownership of oil production, the baseline case of high public ownership is contrasted to the case were oil production is owned by OLG agents in the SOE. In particular, it is assumed that the fiscal authority collects ten percent of the oil rents, relative to the 75 percent in the baseline. This more closely aligns the calibration to countries such as Australia or Canada.

There are two important factors which influence the results when there is a high share of private ownership. First since the majority of oil revenues go to OLG agents and they already smooth a large share of the change in the oil incomes, ceteris paribus, output is less volatile than under a BBR. Second, the oil revenues collected by the fiscal authority are smaller, so a given coefficient in the fiscal rule implies less change in the fiscal balance.

For both the external supply and demand shock, the volatility of inflation is still large, whereas the impact on output under a SSR is very similar. For both cases it is efficient for the fiscal authority to respond countercyclically to the tax revenues gap with $d^{\operatorname{tax}}$ equal to 5, and to the oil-revenues gap with $d^{\text {oil }}$ equal to 2 and 1.8 , for the external supply and demand shock, respectively, as shown in Table 10. Even though the coefficients of responsiveness to the tax-revenue gaps are larger, there is a similar degree of countercyclicality as for the 
baseline calibration. Again, attempts to reduce inflation volatility are limited once output begins to fall and induces an inflation-output tradeoff.

In contrast to an economy with public ownership, private agents do most of the savings in the cyclical revenue in economy with primarily private ownership. The main difference is that consumption tends to be slightly higher when it is publically saved. This arises due to the gain in income from lower future net-tax liabilities when the revenue is publically saved. This simply reflects that the marginal value of a dollar to the government exceeds the marginal value of a dollar to the household.

\subsection{Intensity of Oil in Output/Exports}

The desired response to the oil-revenues gap is decreasing as the share of oil in the economy increases. In an economy that is highly dependent on oil production, the non-oil economy contributes a smaller share to overall demand fluctuations. Merely removing fluctuations in income driven by changes in oil rents greatly dampens aggregate demand volatility. This is particularly true of many OPEC countries and other oil-intensive economies including Iran, Iraq, Libya, Nigeria, Oman, Saudi Arabia, and Yemen. In addition, as an economy increases its dependence on oil in total output, a SSR and CCR lead to larger deficit and debt fluctuations.

Conversely, desired response to the oil-revenues gap is increasing in more diversified economies. The evaluated loss functions are compared for an external supply and demand shock when the SOE has net oil exports of 10 percent of GDP. This constitutes a quarter of total exports which is almost half of that in the baseline calibration. This calibration more closely resembles countries such as Cameroon, Ecuador, Egypt, Indonesia, Papua New Guinea, Russia, Tunisia, and Vietnam. For both the external demand and supply shock, it is efficient to respond countercyclically to the tax revenues gap with $d^{\operatorname{tax}}$ equal to 5 . The efficient coefficient on the oil-revenues gap, $d^{\text {oil }}$, is equal to 1.3 for the external supply shock and 1.2 for the external demand shock.

The efficient coefficients on the oil-revenues gap, $d^{\text {oil }}$, are higher than the baseline calibration primarily for two reasons. First, the volatility of output in the case of a BBR is smaller in more diversified economies, since the royalty fluctuations and incomes are smaller. Second, a larger share of the non-oil economy is exposed to external demand 
pressures. This is especially true for the external demand shocks as the increase in demand for final goods induces income and demand fluctuations. For the case of an external supply shock, the fall in external demand results in the smaller desired degree of countercyclicality, since output begins to fall quickly even though inflation is still quite high, leading to an inflation-output tradeoff.

Kumhof and Laxton (2009a) find that welfare gains are significantly lower for more open economies due to the potentially higher import leakages of fiscal policy in the face of changes in the relative price of oil. The above analysis underscores the importance of commodity intensity in exports. A more open economy with diversified exports in the face of external demand shocks would have a larger gain from a CCR due to the impact on the nonoil economy.

\subsection{Foreign Ownership of Oil}

In an economy with a share of foreign ownership of oil (ceteris paribus), a smaller share of rents is collected domestically by the fiscal authority. If private agents still receive the same share of oil rents, there is a similar degree of domestic demand fluctuation. In this case, the fiscal authority has a similar desired degree of countercyclicality of the fiscal balance. In order to achieve that change, the coefficients in the fiscal rule are larger. When the SOE has a fifty percent foreign claim on oil rents, the fiscal authority's claim on oil rents is a third of the size relative to the baseline. This calibration is consistent with countries that employ joint ownership with foreign companies for production or have claim on the rent of oil production of foreign companies such as Botswana and Papua New Guinea. In this case, for both the external demand and supply shock, it is efficient to respond countercyclically to the tax revenues gap with $d^{t a x}$ equal to 5. The efficient coefficient on the oil-revenues gap, $d^{\text {oil }}$, is equal to 1.6 for the external supply shock and 1.3 for the external demand shock.

\subsection{Composition of the Non-Oil Tax Revenues}

The source of non-oil tax revenues and its share in total revenues affects the operation of the fiscal rule by changing the response of the non-oil tax-revenue gap to business cycles. The non-oil tax-revenue gap serves as a good proxy to observe and adjust income and output fluctuations, because tax revenues adjust with their underlying tax bases: consumption, labor, and capital. However, non-oil revenue fluctuations are reduced in countries that have sizable 
informal labor markets or small non-oil tax revenues. The analysis suggests that a low level of labor tax revenue in total revenues does not pose a limitation to the use of a tax-revenue gap-based rule, because the path of the tax bases respond similarly, even though their magnitudes change. In such a case the size of the coefficients on the tax-revenue gaps can be increased to compensate for the reduced volatility of the tax-revenue gaps, see Table 1 .

\subsection{Oil Intensity in the Consumption Basket}

Kumhof and Laxton (2009a) find that it is not efficient to respond countercyclically to the commodity-revenues gap when faced with an external copper-specific demand or supply shock for the case of Chile. For oil exporters, since oil constitutes a higher share in the consumption basket relative to non-oil commodities, there are larger gains from responding countercyclically to oil revenues due to the higher volatility of headline inflation. If oil is not consumed directly in the consumption basket, the efficient fiscal policy for an external oil supply shock is to respond less to the oil revenues' gap with $d^{\text {oil }}$ equal to 1.05 , as shown in Table 10. In such a case, the fiscal authority has a less inflation volatility and can respond to the inflation volatility without sacrificing output volatility. This suggests that the efficient size of the countercyclical fiscal response to an external oil supply shock (or commodity-specific demand shock) increases with the share of the commodity in the consumption basket. ${ }^{13}$

However, for the external demand shock, if oil is not consumed directly in the consumption basket, the efficient fiscal policy for an external oil supply shock is to respond more aggressively to the oil revenues' gap with $d^{\text {oil }}$ equal to 1.5 , as shown in Table 10 . In such a case, the response of inflation and output are more closely correlated and the fiscal authority can respond to the remaining inflation volatility in the economy without sacrificing output volatility. This suggests that the efficient size of the countercyclical fiscal response to

\footnotetext{
${ }^{13}$ Quantifying the efficient cyclical fiscal policy for other types of commodities will depend on the characteristics of those markets in conjunction with the structure of the economy. For example, the impact on headline inflation might be more pronounced for agricultural goods, since they constitute a large share in the consumption basket in developing economies. Also, commodity characteristics, such as domestic demand and supply elasticities, the heterogeneity of commodity prices across regions, and the amount of production rents, might influence the design of efficient policy. Countries that are more diversified across commodities are less likely to experience domestic fluctuations from external supply shocks compared with broad-based external demand shocks. Moreover, structural characteristics such as public ownership are more applicable to metal and oil production than to agricultural commodities.
} 
the oil-revenues gap for the case of an external demand shock decreases with the share of the commodity in the consumption basket.

\section{Implications under Alternative Policy Assumptions}

This section considers alternative policy assumptions around the baseline for the design of the preferred fiscal rule. In particular, four cases are considered: (i) when monetary policy employs a fixed exchange regime, (ii) when fiscal and monetary policies are jointly optimized, (iii) when the fiscal authority is concerned with debt volatility, and (iv) when the fiscal authority is concerned with welfare volatility. In all cases, a CCR is found to reduce volatility relative to an SSR.

\subsection{Fixed Exchange Rate Regimes}

This section compares the optimization of the cyclical fiscal rule in conjunction with fixed exchange rate monetary policy regimes. The SOE targets the nominal bilateral exchange rate with the rest of the world as described in Kumhof and others (2010). Under a fixed exchange rate regime, the SOE imports the monetary policy of the rest of the world to equalize the returns on assets across the two countries as per the uncovered interest parity condition to achieve a fixed nominal bilateral exchange rate. The preoccupation of monetary policy with its fixed exchange rate policy induces more macroeconomic volatility than under an inflation-targeting regime, consistent with empirical findings (see also Adler and Sosa, 2011; Broda, 2004; Kaminsky, 2010; and Rafiq, 2011).

A fixed exchange rate regime is one circumstance that Taylor (2000) proposes when discretionary fiscal policy can enhance macroeconomic stability. This is the case for the oilexporting SOE since a move to a SSR results in the largest reduction in volatility relative to the BBR compared to all other types of sensitivity analysis examined. The relative gains of adopting a CCR over a SSR are larger under a fixed exchange rate regime primarily due to the higher volatility under a SSR. However, fiscal policy comes with a higher cost over the medium term since monetary policy cannot respond to the persistent changes in net-worth of households from the change in public net debt. This makes aggressive countercyclical fiscal policy unfeasible and results in higher volatility under the efficient CCR.

For the case of an external supply shock, it is efficient for fiscal policy to respond countercyclically by a similar degree to the baseline assumptions due a similar profile of a 
slightly easing of monetary policy, see Table 3. Additional countercyclicality would result in an increase in output volatility. For the external demand shock the efficient CCR requires more fiscal adjustment than for the baseline. The efficient CCR results in larger output and inflation variability than an inflation-targeting regime, as shown in Figures 7 and 8. Figures 9.A and 10.A show a policy efficiency frontier for the temporary shocks under a fixed exchange rate regime. The curve is much steeper and kinked implying a much larger reduction in output volatility for a given increase in inflation volatility relative to an inflation-targeting regime.

\subsection{Joint Monetary Policy Considerations}

The above analysis assumes that the monetary authority responds with a coefficient of 1.5 to the deviation of core inflation from the target level. This calibration is consistent with findings for the joint optimization of monetary and fiscal policy in Bi and Kumhof (2011). However, similar to Coletti and others (2012), the small open oil exporter faces the problem of headline inflation variability with an inability to control the global price of oil. This creates an inflation-output tradeoff since domestic activity in non-oil sectors would need to fall to further reduce headline inflation. A more credible and aggressive monetary policy allows for a less countercyclical response of fiscal policy.

For the case of an external supply shock, core inflation falls very slightly under a CCR so although it is slightly more efficient for monetary policy to respond aggressively to the deviation of core from target, with $d^{\pi}$ equal to 5 , it does very little to reduce volatility. An aggressive monetary policy response to headline inflation results in a smaller non-oil tax revenue gap. Even though the efficient response to the oil-revenues gap, $d^{\text {oil }}$, is 1.3 , less of a countercyclical response of the fiscal balance is required. More aggressive monetary policy can substitute for the countercyclical fiscal response, as shown in Table 12.

In the case of an external demand shock, core inflation rises under a CCR, and it is efficient for the monetary policy to respond aggressively, with $d^{\pi}$ equal to 5 . This results in a smaller increase in the non-oil tax-revenue gap and a slightly less countercyclical fiscal policy. In such a scenario, volatility can be reduced by an additional 10 per cent relative to the baseline scenario. Targeting headline inflation results in a jump in interest rates in the 
short run and a larger fall in output. In such a case, there is more macroeconomic volatility relative to targeting core inflation.

\subsection{Debt Volatility}

A non-BBR response invokes net savings volatility that creates macroeconomic consequences due to expected future changes in taxes or spending and changes in the borrowing costs. This paper considers the case where the sovereign risk premium does not respond to the debt level, consistent with the assumption of operating from a sovereign wealth fund or a low net debt position. Further, the relatively small size of the SOE implies that it should have no impact on the global equilibrium real interest rate. ${ }^{14}$ However, it is still the case that a change in the net debt level is returned to the level implied by the surplus target by the nominal rate of growth, $5 \%$ per annum. Hence, a decrease in public net debt causes a small, but persistent, increase in the net worth of households.

To assess if this adjustment in the net debt position is efficient, the coefficients on the tax-and oil-revenues gaps are jointly searched with the coefficient on the net debt level deviation from its implied target, $d^{d e b t}$. As shown in Table 3, the analysis suggests that the baseline non-responsiveness to net debt in the fiscal rule is efficient, $d^{\text {debt }}$ equal to zero, under the above-mentioned assumptions. This result is robust to alternative assumptions of the instrument satisfying the fiscal rule.

\subsection{Policy Objectives}

The objective function of the fiscal authority thus far is assumed to be business-cycle stabilization, which will now be contrasted with welfare based measures. An approximation of welfare is computed by evaluating the average utility functions across generations weighted by the share of OLG and LIQ agents. The model is simulated using a NewtonRaphson stacked-time algorithm to solve for the exact nonlinear solution. When the above analysis is replicated using welfare maximization as an objective, first-order effects are found to dominate second-order effects. When the above analysis is replicated with an objective to

\footnotetext{
${ }^{14}$ This may be an unreasonable assumption if all commodity exporters' savings react in an identical fashion. In such a case the joint savings of all oil revenues, if large enough, could have consequences for the global equilibrium real interest rate.
} 
minimize the volatility of welfare, consistent with an objective to minimize consumption and labor volatility, interesting implications arise.

Since LIQ agents are not assumed to receive the rents from oil, there is little need to smooth their consumption from changes in oil rents. ${ }^{15}$ The majority of the variability in real GDP in the SOE from an external oil-price shock is from net exports. The efficient fiscal policy is a SSR with slight procyclical elements. This is due to the disutility from increased labor supply, which can be offset by a small increase in consumption. This result is precarious primarily due to the absence of the extensive margin of labor. Hence, an increase in labor, although it could be a reduction in unemployment, is always counted as a disutility. In contrast, when minimizing consumption volatility, the efficient rule remains countercyclical. Thus, it is found that the desired degree of countercycality is increasing in the importance placed on output volatility relative to welfare volatility.

\section{Conclusions}

This paper evaluates the appropriateness of budget-balance tax-gap rules for oil exporters. Countercyclical budget-balance rules are found to be well suited to stabilize the macroeconomic volatility of oil-exporting countries. A larger countercyclical response is warranted for external demand-driven shocks relative to external supply-driven shocks due to their impact on the non-oil economy. Oil exporters face unique volatility in headline inflation due to oil's importance in the consumption basket. The efficient response to the oil-revenues gap depends on the share of oil in the consumption basket.

The underlying structural characteristics of the commodity exporter influence the appropriate policy response. In an economy with a share of foreign ownership of oil, less oil production in total output, and higher private domestic ownership, the fiscal authority collects a smaller share of rents. A countercyclical rule is preferred, but the response to the revenues gaps must increase to achieve a similar degree of stabilization.

The majority of the response generated in the small open economy from an external oil-price shock is the increase in GDP from a rise in net exports. Thus, the desired degree of

\footnotetext{
${ }^{15}$ For the case then LIQ agents do receive a share of the oil rents the baseline results are consistent with the findings of Kumhof and Laxton (2010) and Bi and Kumhof, (2011).
} 
countercycality is increasing in the importance placed on output volatility relative to consumption volatility. Further, the fiscal authority does not need to respond to changes in the net debt position if they are operating in an environment where the interest rate is unresponsive to changes in net savings positions. The size and source of non-oil tax revenues do not pose limitations on the use of a tax-revenue-gap fiscal rule, since the dynamics of tax bases are similar and the size of the coefficients on the tax-revenue gaps can increase to compensate for the reduced volatility of the tax-revenue gaps.

Joint coordination of countercyclical monetary and fiscal policy creates more flexibility for the authorities to reduce inflation and output variability. Overall, it is preferable for monetary policy to respond to the core inflation deviation and for fiscal policy to follow countercyclical fiscal rule. The gains from moving to a structural surplus rule are largest under a fixed exchanges rate policy. While a countercyclical fiscal rule is preferred over a structural surplus fiscal rule, fiscal effort must increase and cannot achieve the degree of stabilization as a core-inflation targeting regime. A fixed exchange rate increases the cost of changes in the level of net debt and counteracts the gains from fiscal policy.

In general, oil exporters have been moving in the right direction. Some are already operating effectively under a structural or countercyclical fiscal rule or are in the process of formalizing fiscal institutions. However, countries await further gains from formalized fiscal policy frameworks. Fortunately, the gains from these rules are robust to many of the structural characteristics and policy environments that differ across oil exporters. 


\section{REFERENCES}

Adler, G., and S. Sosa, 2011, "Commodity Price Cycles: The Perils of Mismanaging the Boom," IMF Working Paper No. 11/283

Anderson, D., B. Hunt, M. Kortelainen, M. Kumhof, D. Laxton, D. Muir, S. Mursula and S. Snudden. 2013, "Global Integrated Monetary and Fiscal Model (GIMF) - Model Properties.” IMF Working Paper No. 13/55

Barnett, S. and O. Rolando, 2003, "Operational Aspects of Fiscal Policy in Oil-Producing Countries," in J. Davis, R. Ossowski and A. Fedelino (eds.), Fiscal Policy Formulation and Implementation in Oil-Producing Countries, International Monetary Fund, Washington, D.C.

Baunsgaard, T., M. Villafuerte, M. Poplawski-Ribeiro, and C. Richmond, 2012, "Fiscal Frameworks for Natural-Resource-Intensive Developing Countries," IMF Staff Discussion Note 12/04.

Berg, A., Portillo, R., Yang, S. C. S., and Zanna, L. F, 2013, "Public Investment in ResourceAbundant Developing Countries," IMF Economic Review, 61(1), 92-129.

Bernanke, B., M. Gertler and S. Gilchrist, 1999, “The Financial Accelerator in a Quantitative Business Cycle Framework," in John B. Taylor and Michael Woodford, (eds.), Handbook of Macroeconomics, Volume 1C, Amsterdam: Elsevier.

Bi, H., and M. Kumhof, 2011, "Jointly optimal monetary and fiscal policy rules under liquidity constraints," Journal of Macroeconomics, vol. 33(3), pages 373-389, September.

Blanchard, O., 1985, "Debt, Deficits, and Finite Horizons," Journal of Political Economy, Vol. 93, pages. 223-247.

Broda, C., 2004, "Terms of Trade and Exchange Rate Regimes in Developing Countries" Journal of International Economics, Vol. 63, pages 31-58.

Canales-Kriljenko, J. I., C. Freedman, R. Garcia-Saltos, and D. Laxton, 2009, “Adding Latin America to the Global Projection Model." IMF Working Paper No. 09/85

Céspedes, L.F., and A. Velasco, 2011, "Was This Time Different? Fiscal Policy in Commodity Republics," Bank of International Settlements Working Paper No. 365

Coenen, G., C. Erceg, C. Freedman, D. Furceri, M. Kumhof, R. Lalonde, D. Laxton, J. Lindé, A. Mourougane, D. Muir, S. Mursula, C. de Resende, J. Roberts, W. Roeger, S. Snudden, M. Trabandt, and J. in 't Veld, 2012, "Effects of Fiscal Stimulus in Structural Models," American Economic Journal: Macroeconomics, 4(1), pages. 2268. 
Coletti, D., R. Lalonde, P. Masson, D. Muir, and S. Snudden, 2012, "Commodities and Monetary Policy: Implications for Inflation and Price Level Targeting." Bank of Canada Working Paper 12-16.

Collier, P., F. van der Ploeg, M. Spence, and A. J. Venables, 2010, "Managing Resource Revenues in Developing Economies," IMF Staff Papers No. 51, Vol. 7, pages. 84118.

Davis, J., R. Ossowski, J. Daniel, and S. Barnett, 2002, "Stabilization and Savings Funds for Non-Renewable Resources: Experience and Fiscal Policy Implications," IMF Occasional Paper No. 205.

Deaton, A., and G. Laroque, 1992, “On the Behaviour of Commodity Prices," Review of Economic Studies, vol. 59, No. 1, pages. 1-23.

Duttagupta, R., J, Bluedorn, and A. Pescatori., and S. Snudden, 2012, "Commodity Price Cycles and Commodity Exporters," Chapter 4 of the World Economic Outlook, International Monetary Fund April 2012.

Eyzaguirre, N., M. Kaufman, S. Phillips, and R. Valdés, 2011, "Managing Abundance to Avoid a Bust in Latin America," IMF Staff Discussion Note 11/07.

Frankel, J. A., Vegh, C. A., and Vuletin, G, 2013, “On Graduation from Fiscal Procyclicality," Journal of Development Economics." Vol. 100, Issue 1, pages. 32-47

Garcia, C., J. Restrepo, and E. Tanner, 2011, "Fiscal rules in a volatile world: A welfarebased approach", Journal of Policy Modeling, Volume 33, Issue 4.

Gavin, M., and R. Perotti, 1997, "Fiscal Policy in Latin America." In: B. Bernanke and J. Rotemberg, eds. NBER Macroeconomics Annual 1997. Cambridge, MA. MIT Press.

Girouard, N. and C. André, 2005, "Measuring Cyclically Adjusted Budget Balances for OECD Countries," OECD Economics Department Working Papers, No. 434, OECD Publishing.

Hogan, S., M. Johnson, and T. Laflèche, 2001, “Core Inflation,” Bank of Canada Technical Report, 2001-89.

Husain, A. M., K. Tazhibayeva, and A. Ter-Martirosyan, 2008, "Fiscal Policy and Economic Cycles in Oil-Exporting Countries," IMF Working Paper No. 08/253.

International Monetary Fund, 2009, "Fiscal Rules-Anchoring Expectations for Sustainable Public Finances," IMF Policy Paper (December 16, 2009).

International Monetary Fund, 2012, "Macroeconomic Policy Frameworks for Resource-Rich Developing Countries," IMF Policy Paper (August 24, 2012). 
Kaminsky G., C., 2010, “Terms of Trade Shocks and Fiscal Cycles,” RBA Annual Conference Volume, in: Fry R., C. Jones, and C. Kent (ed.), Inflation in an Era of Relative Price Shocks, Reserve Bank of Australia.

Kaminsky, G., C. Reinhart, and C. Vegh, 2004, "When it Rains it Pours: Procyclical Capital Flows and Macroeconomic Policies" in Mark Gertler and Kenneth Rogoff (eds.) NBER Macroeconomics Annual 2004. Cambridge, MA. MIT Press.

Kumhof, M., and D. Laxton, 2009a, "Simple, Implementable Fiscal Policy Rules," IMF Working Paper No. 09/76.

Kumhof, M., and D. Laxton, 2009b, "Fiscal Deficits and Current Account Deficits," IMF Working Paper No. 09/237.

Kumhof, M., and D. Laxton, 2010, “Chile's Structural Fiscal Surplus Rule: a Model-Based Evaluation," Journal Economía Chilena (The Chilean Economy), Central Bank of Chile, vol. 13(3), pages 5-32, December.

Kumhof, M., D. Laxton, D. Muir and S. Mursula, 2010, “The Global Integrated Monetary Fiscal Model (GIMF) — Theoretical Structure," IMF Working Paper No. 10/34.

Medas, P., and D. Zakharova, 2009, “A Primer on Fiscal Analysis in Oil-Producing Countries," IMF Working Paper No. 09/56.

Medina, L., 2010, “The Dynamic Effects of Commodity Prices on Fiscal Performance in Latin America," IMF Working Paper No. 10/192.

Natal, J.M., 2012, "Monetary Policy Response to Oil Price Shocks," Journal of Money, Credit and Banking, vol. 44(1), pages 53-101.

Rafiq, M., 2011, "Sources of Economic Fluctuations in Oil-Exporting Economies: Implications for Choice of Exchange Rate Regimes", International Journal of Finance and Economics, vol.16, pages 70-91.

Schaechter, A., T. Kinda, N. Budina, and A. Weber, 2012, "Fiscal Rules in Response to the Crisis - Toward the 'Next-Generation Rules: A New Dataset,' IMF Working Paper No. 12/187.

Talvi, E., and C. Vegh, 2005, "Tax Base Variability and Procyclicality of Fiscal Policy," Journal of Development Economics, 78, pages 156-190.

Taylor, John B, 2000, “Reassessing Discretionary Fiscal Policy,” Journal of Economic Perspectives, vol. 14(3), pages 21-36

Varangis, P. N., Akiyama, T., and Mitchell, D, 1995, "Managing commodity booms--and busts." World Bank Publications. 


\section{TABLES AND Figures}

\begin{tabular}{|c|c|c|c|c|c|c|}
\hline Table 1: Optimal Fiscal Rule by Sour & $d^{\text {oil }}$ & $d^{\operatorname{tax}}$ & $\begin{array}{l}\text { ation and } \\
\text { Efficient } \\
\text { less SSR/ } \\
\text { GDP }^{16}\end{array}$ & $\begin{array}{c}\text { aracteristi } \\
\text { Loss } \\
\text { Function } \\
\text { SSR } \\
\end{array}$ & $\begin{array}{l}\text { of the SOF } \\
\text { Loss } \\
\text { Function } \\
\text { Efficient }^{17} \\
\end{array}$ & $\begin{array}{c}\text { Loss } \\
\text { Function } \\
\text { Gain } \\
\end{array}$ \\
\hline \multicolumn{7}{|l|}{ Temporary Reduction in Oil Supply } \\
\hline Baseline & 1.2 & 5 & 0.39 & 0.08 & 0.06 & $23 \%$ \\
\hline Private Ownership of Oil Production & 2 & 5 & 0.32 & 0.06 & 0.05 & $17 \%$ \\
\hline Low Dependence of Oil in Exports/Production & 1.3 & 5 & 0.42 & 0.07 & 0.06 & $19 \%$ \\
\hline High Dependence of Oil in Exports/Production & 1.2 & 5 & 0.56 & 0.11 & 0.08 & $28 \%$ \\
\hline Foreign Share in Ownership of Oil Production & 1.6 & 5 & 0.35 & 0.06 & 0.05 & $18 \%$ \\
\hline Low Level of Labor Taxes in Total Revenue & 1.2 & 5 & 0.46 & 0.07 & 0.06 & $21 \%$ \\
\hline No Direct Consumption of Oil & 1.05 & 5 & 0.17 & 0.03 & 0.02 & $32 \%$ \\
\hline \multicolumn{7}{|l|}{ Temporary Increase in Liquidity } \\
\hline Baseline & 1.1 & 5 & 0.45 & 0.13 & 0.10 & $18 \%$ \\
\hline Private Ownership of Oil Production & 1.8 & 5 & 0.55 & 0.12 & 0.10 & $14 \%$ \\
\hline Low Dependence of Oil in Exports/Production & 1.2 & 5 & 0.59 & 0.13 & 0.10 & $18 \%$ \\
\hline High Dependence of Oil in Exports/Production & 1.1 & 5 & 0.3 & 0.15 & 0.12 & $18 \%$ \\
\hline Foreign Share in Ownership of Oil Production & 1.3 & 5 & 0.57 & 0.13 & 0.10 & $19 \%$ \\
\hline Low Level of Labor Taxes in Total Revenue & 1.2 & 5 & 0.61 & 0.13 & 0.11 & $16 \%$ \\
\hline No Direct Consumption of Oil & 1.5 & 5 & 0.81 & 0.11 & 0.08 & $27 \%$ \\
\hline
\end{tabular}

\begin{tabular}{|c|c|c|}
\hline \multicolumn{3}{|c|}{ Table 2: Two Year Multiplier of Fiscal Instruments ${ }^{18}$} \\
\hline & Real GDP & Headline Inflation \\
\hline Public Absorption & 0.53 & 0.28 \\
\hline Public Investment & 0.64 & 0.34 \\
\hline General Transfers & 0.14 & 0.23 \\
\hline Targeted Transfers & 0.32 & 0.50 \\
\hline Labor Taxes & 0.25 & 0.22 \\
\hline Consumption Taxes & 0.20 & -0.48 \\
\hline
\end{tabular}

\footnotetext{
${ }^{16}$ This measure is the difference of the overall fiscal balance between the efficient fiscal policy rule and the SSR as a percent of GDP.

${ }^{17}$ This is the evaluated loss function of the efficient fiscal policy rule.

${ }^{18}$ This multiplier is the two year average of the percent deviation from steady state increase in real GDP over the two year average of the difference of the overall fiscal balance to GDP ratio from steady state.
} 
Table 3: Efficient Fiscal Rule by Source of Oil Price Fluctuation and Policy
Efficient Loss

\begin{tabular}{lllcccc}
$d^{o i l}$ & $d^{\text {tax }}$ & $d^{* 19}$ & $\begin{array}{c}\text { less SSR/ } \\
\text { GDP }^{20}\end{array}$ & $\begin{array}{c}\text { Function } \\
\text { SSR }^{21}\end{array}$ & $\begin{array}{c}\text { Function } \\
\text { Efficient }^{22}\end{array}$ & $\begin{array}{c}\text { Function } \\
\text { Gain }\end{array}$ \\
\hline
\end{tabular}

\section{Temporary Reduction in Oil Supply}

Baseline

General Transfers Satisfying the Fiscal Rule

$\begin{array}{llll}1.2 & 5 & - & 0.4\end{array}$

Fixed Exchange Rate

$1.45-$

0.4

0.08

0.06

$23 \%$

$1.25-$

0.7

0.06

0.05

$29 \%$

Joint Reaction to Debt and Fiscal Tax Gaps

$\begin{array}{lll}1.2 & 5 & 0\end{array}$

0.4

0.09

0.06

$28 \%$

$\begin{array}{lll}1.2 & 5 & 5\end{array}$

0.4

0.08

0.06

$23 \%$

Joint Core Monetary and Fiscal Tax Gaps

$1.3 \quad 5 \quad 5$

0.3

0.08

0.06

$23 \%$

Joint Headline Monetary and Fiscal Tax Gaps

Temporary Increase in Liquidity

Baseline

General Transfers Satisfying the Fiscal Rule

Fixed Exchange Rate

Joint Reaction to Debt and Fiscal Tax Gaps

Joint Core Monetary and Fiscal Tax Gaps

Joint Headline Monetary and Fiscal Tax Gaps

\begin{tabular}{ccccccc}
1.1 & 5 & - & 0.5 & 0.13 & 0.10 & $18 \%$ \\
1.2 & 5 & - & 0.6 & 0.12 & 0.10 & $18 \%$ \\
1.0 & 5 & - & 0.9 & 0.26 & 0.21 & $19 \%$ \\
1.1 & 5 & 0 & 0.5 & 0.13 & 0.10 & $18 \%$ \\
1.1 & 5 & 5 & -0.1 & 0.13 & 0.08 & $34 \%$ \\
1.1 & 5 & 5 & -0.4 & 0.13 & 0.12 & $6 \%$ \\
\hline
\end{tabular}

\footnotetext{
${ }^{19}$ The coefficient on the other instrument being optimized: $d^{\text {debt }}$ for efficient debt adjustment, $d^{\pi}$ for core inflation targeting, $d^{\Pi}$ for headline inflation targeting.

${ }^{20}$ This measure is the difference of the overall deficit between the efficient fiscal policy rule and the SSR as a percent of GDP in the first year proceeding the shock.

${ }^{21}$ For the joint exercises, the SSR rule reported is the same under the baseline assumptions.

${ }^{22}$ This is the evaluated loss function of the efficient fiscal policy rule.
} 
Figure 1: Temporary Reduction in Oil Supply in the Rest of the World, Effects on the Rest of the World $(x$-axis in years)
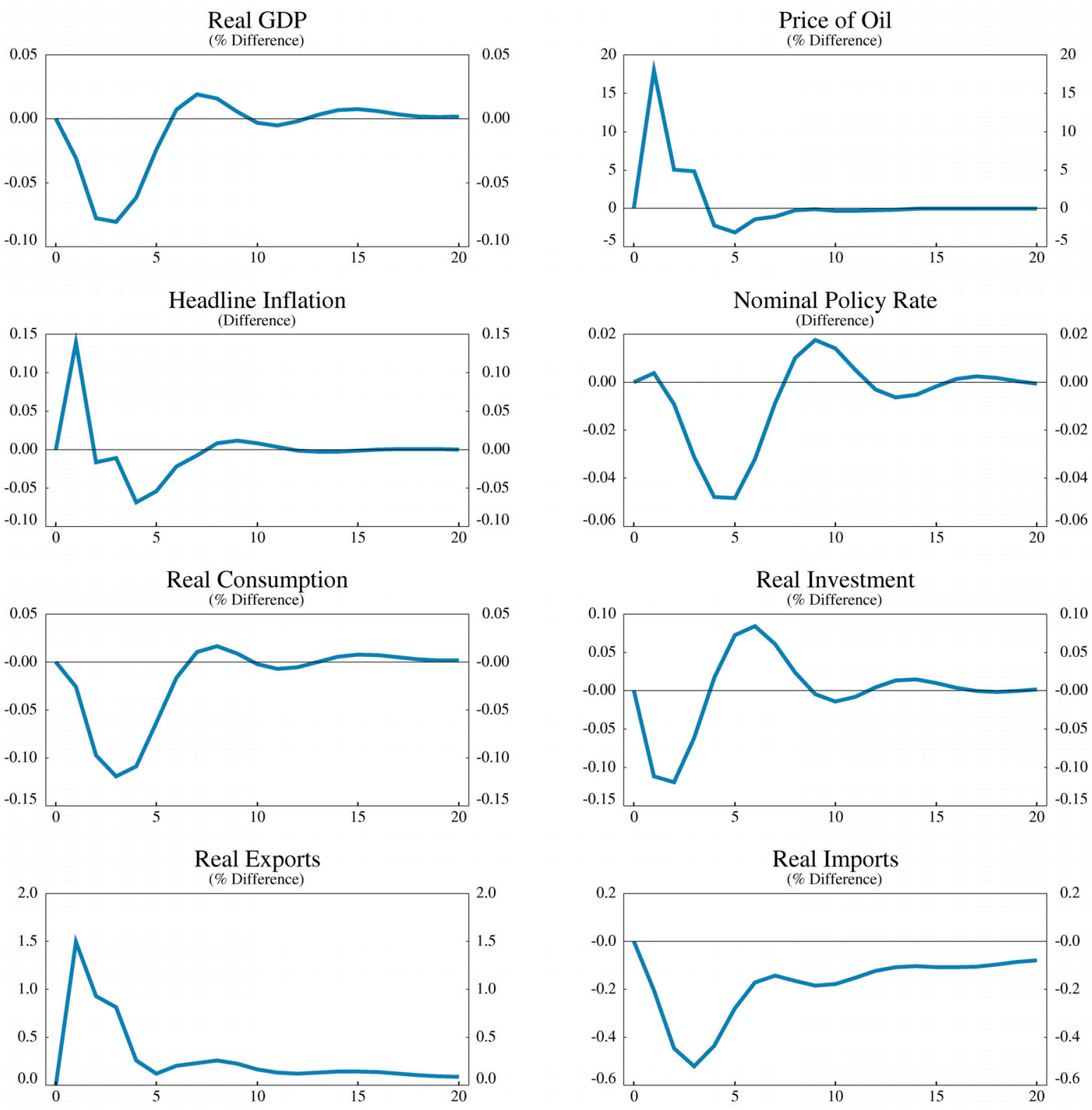

Real Interest Rate
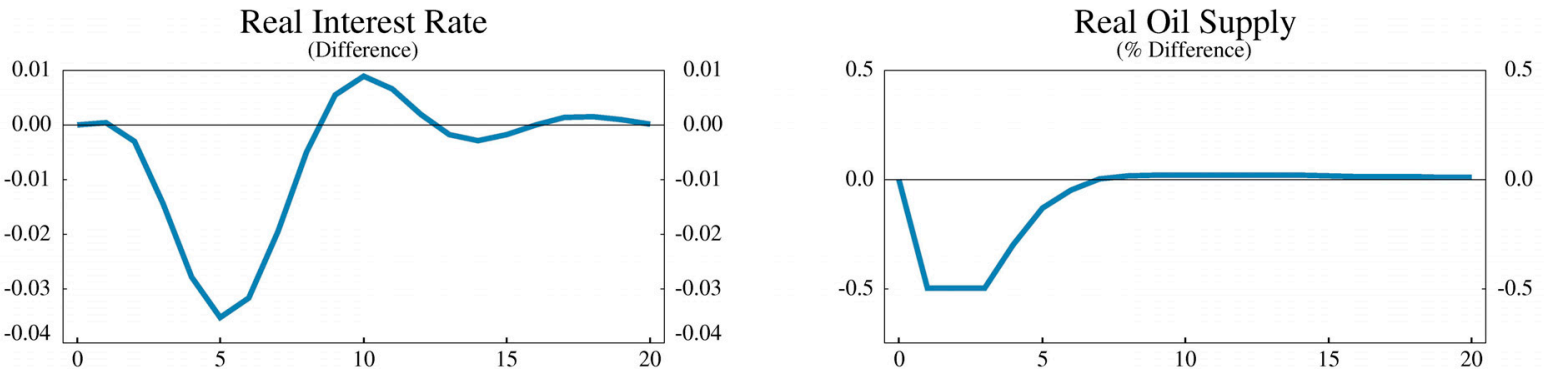


\section{Figure 2: Temporary Reduction in Oil Supply in the Rest of the World, Effects on the SOE \\ (x-axis in years)}

Balanced Budget Rule

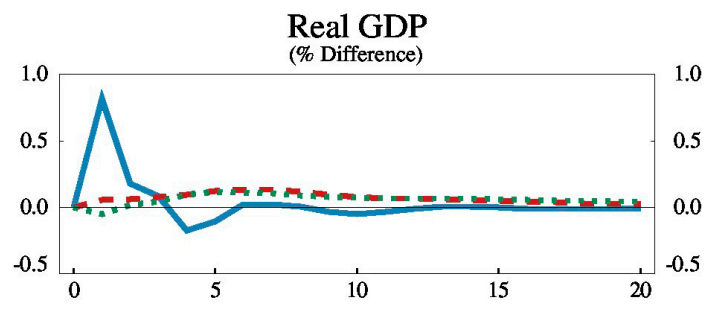

Real Interest Rate

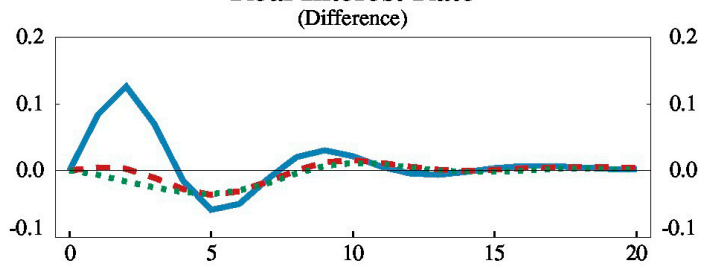

Tax Revenue Gap

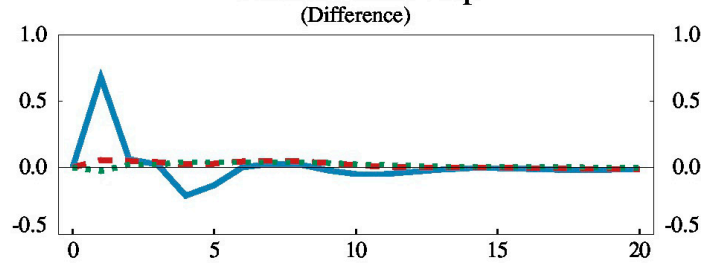

Tax Revenue/GDP

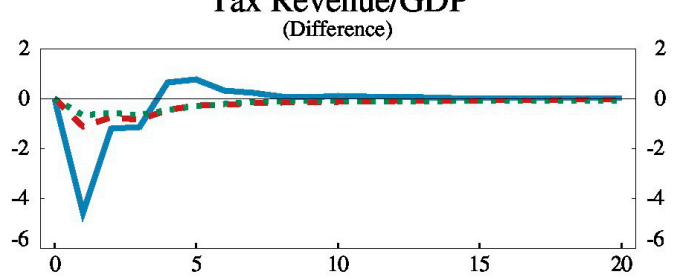

Government Deficit/GDP

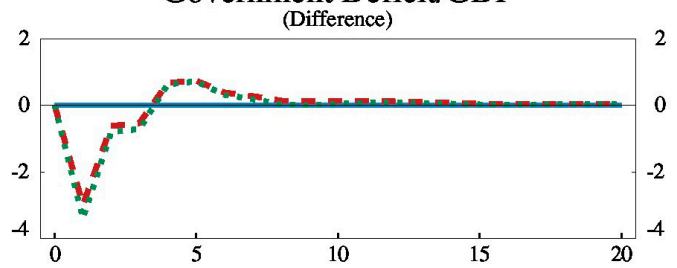

Real Bilateral Exchange Rate

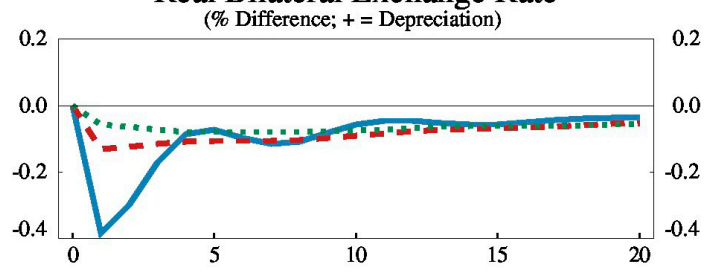

... Optimal Rule (d-oil 1.2, d-tax 5)

Headline Inflation

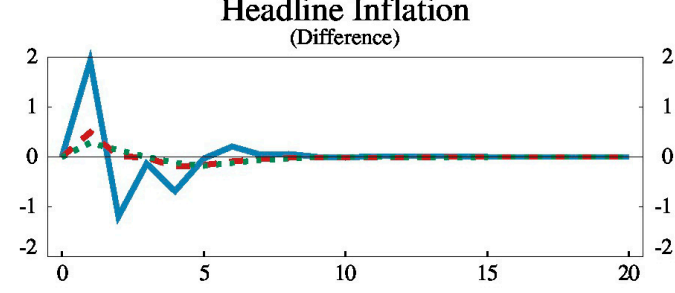

Price of Oil

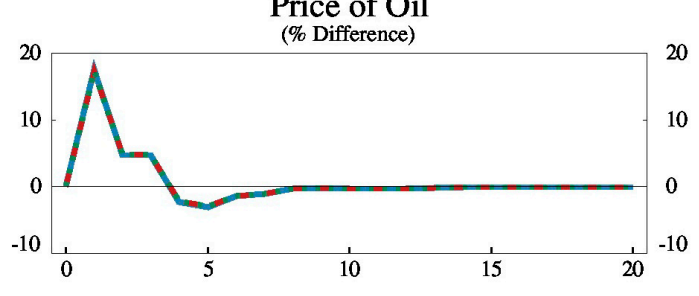

Commodity Royalities Gap

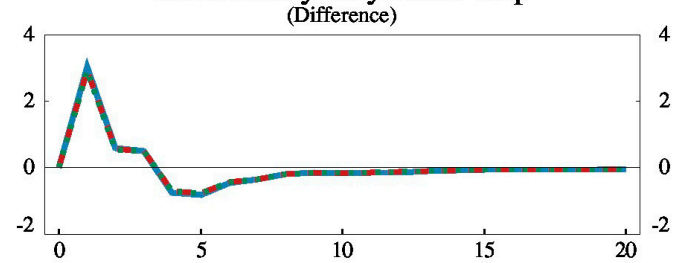

Labor Tax Rate

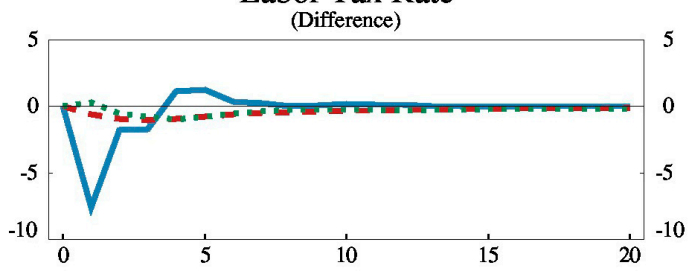

Domestic Gov't Debt/GDP

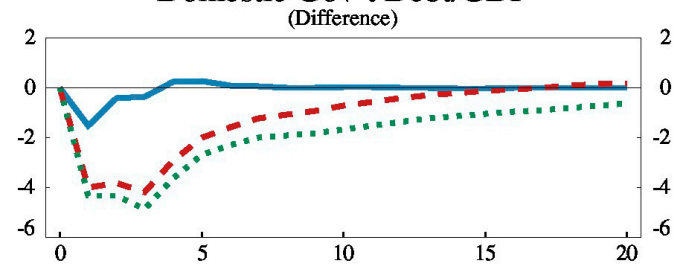

Current Account/GDP

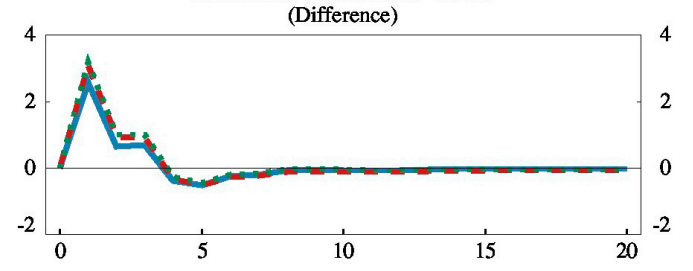


Figure 3: Temporary Increase in Liquidity in the Rest of the World, Effects on the Rest of the World $(\mathrm{x}$-axis in years)
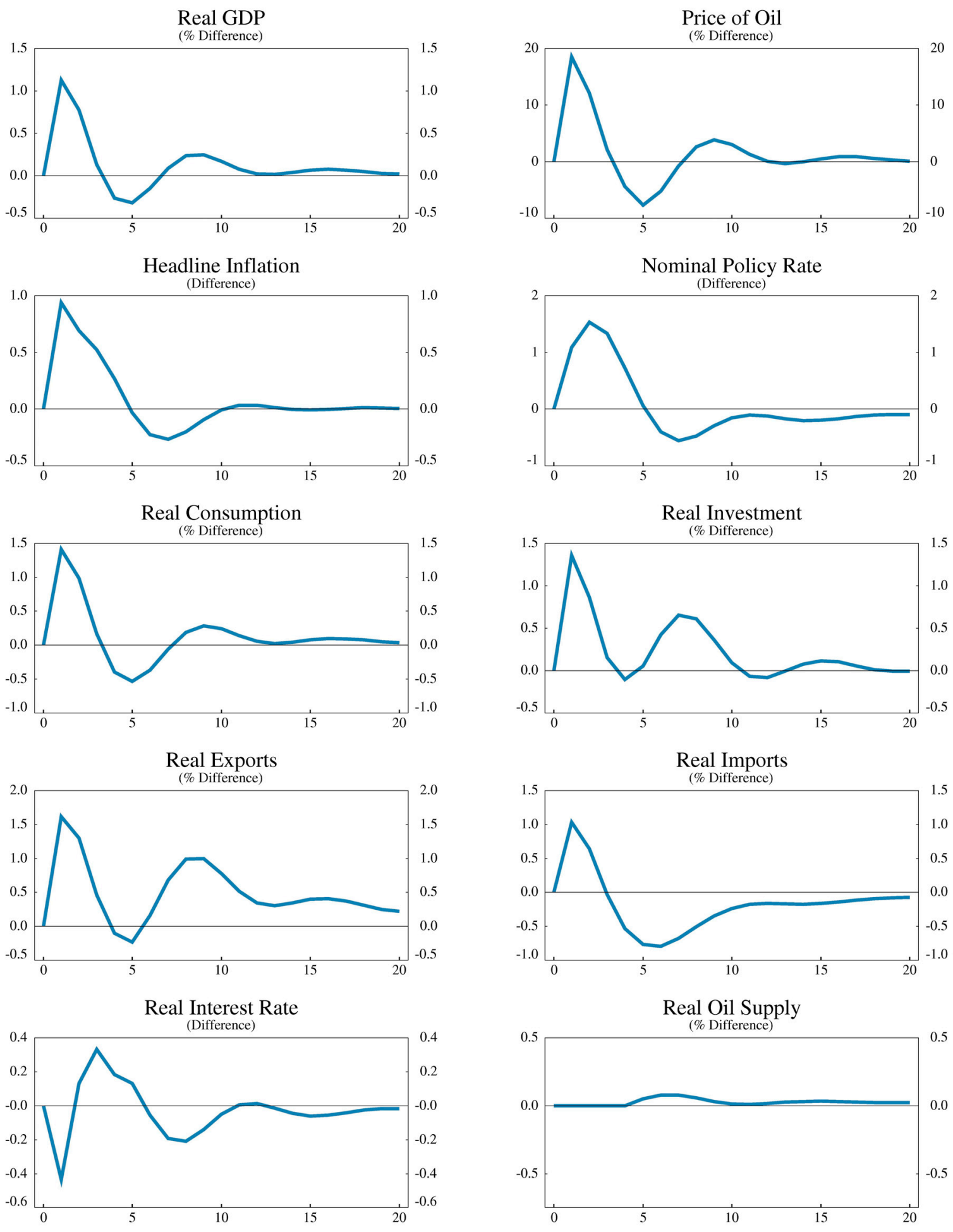
Figure 4: Temporary Increase in Liquidity in the Rest of the World, Effects on the SOE

( $\mathrm{x}$-axis in years)
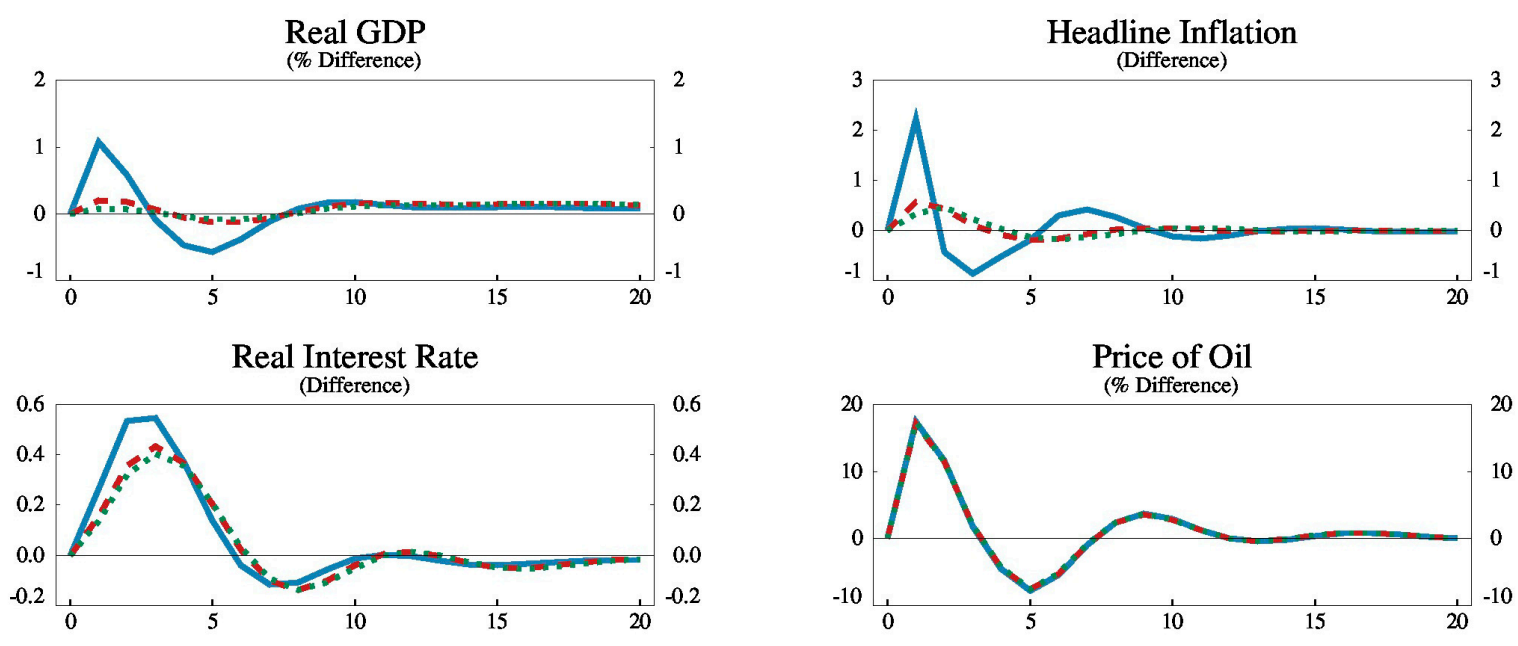

Price of Oil

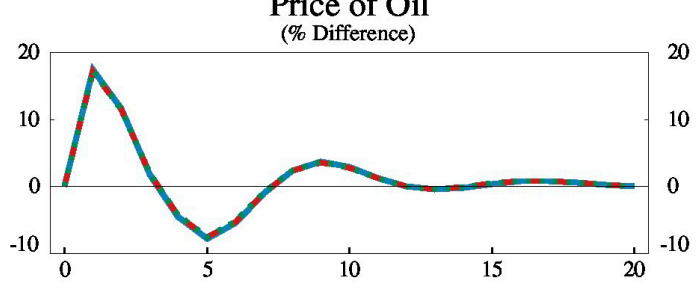

Tax Revenue Gap

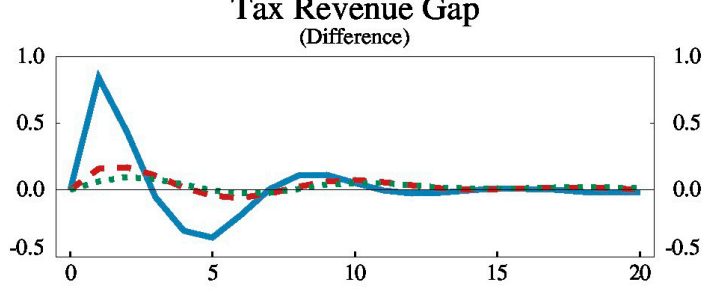

Commodity Royalities Gap

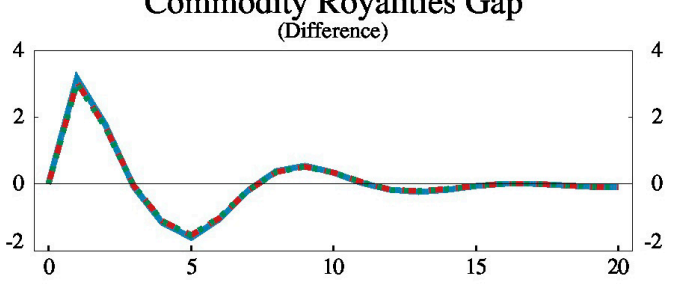

Tax Revenue/GDP

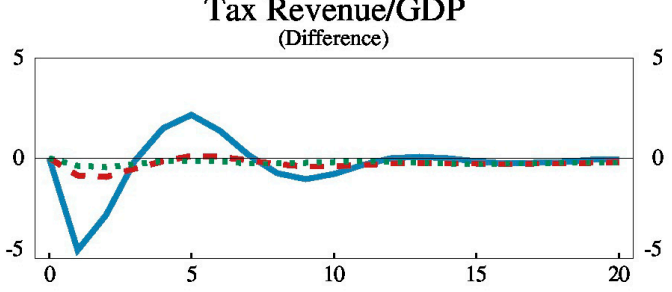

Labor Tax Rate

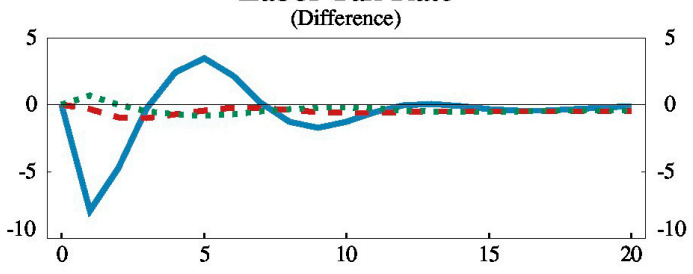

Government Deficit/GDP

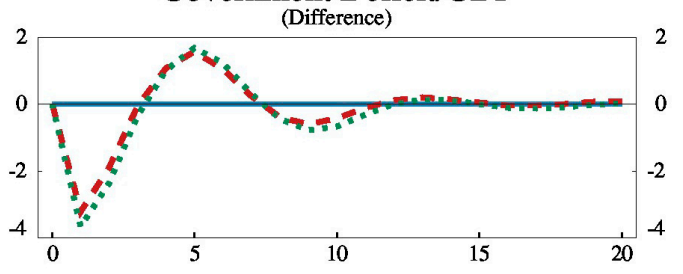

Domestic Gov't Debt/GDP

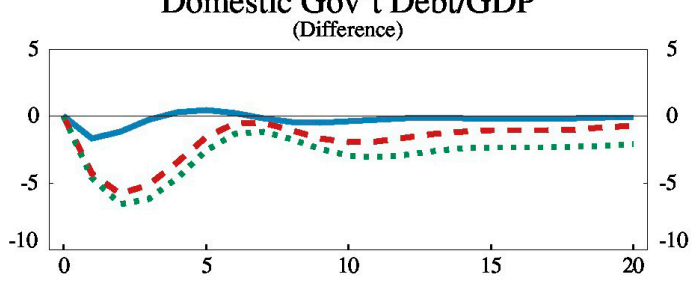

Real Bilateral Exchange Rate
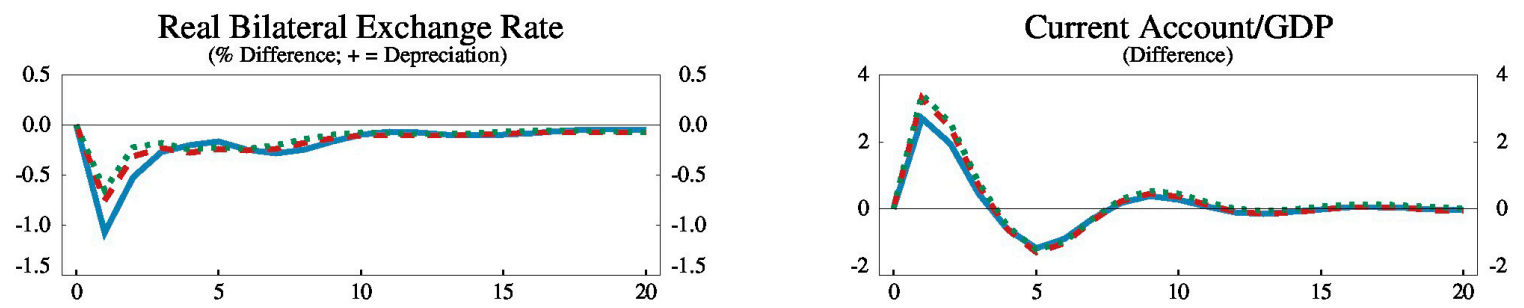
Figure 5 and 5.A: Temporary Reduction in Oil Supply in the Rest of the World, Evaluated Loss Function and Policy Efficiency Frontier

(Optimal Rule at $\lambda_{Y}=1: d^{\text {oil }}=1.2, d^{\text {tax }}=5$ )
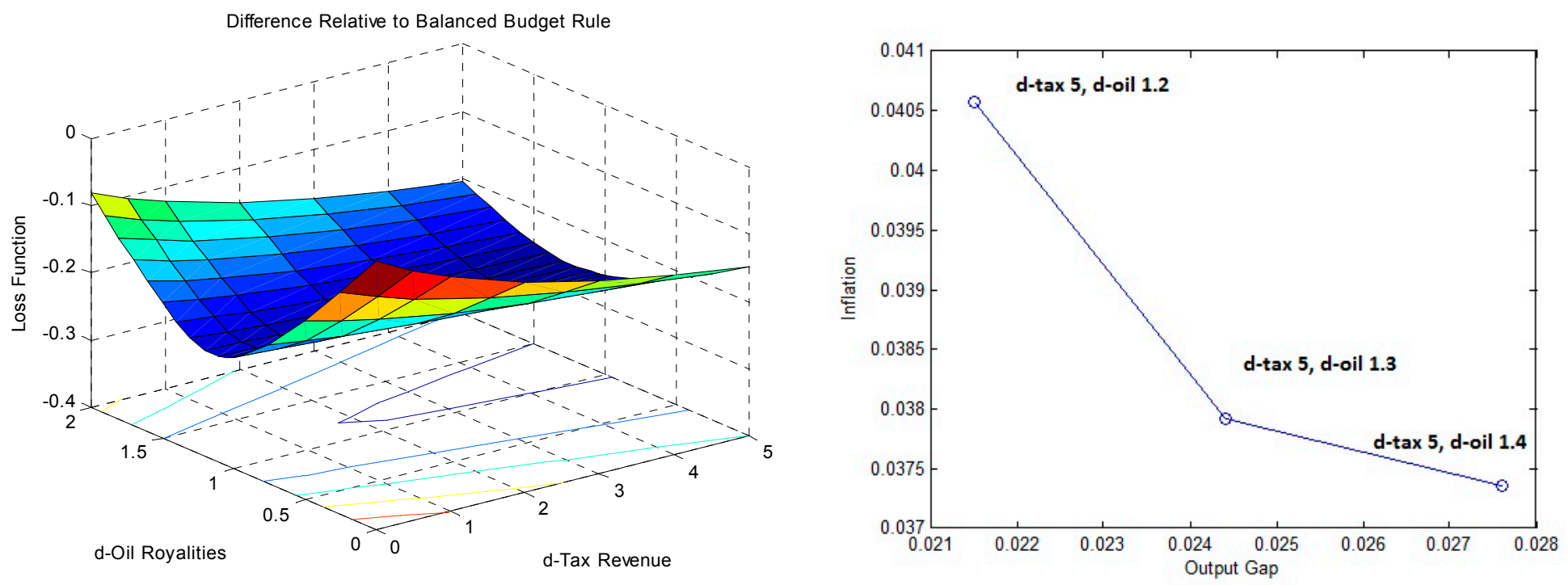

Figure 6 and 6.A: Temporary Increase in Liquidity in the Rest of the World, Evaluated Loss Function

(Optimal Rule at $\lambda_{Y}=1: d^{\text {oil }}=1.1, d^{\text {tax }}=5$ )
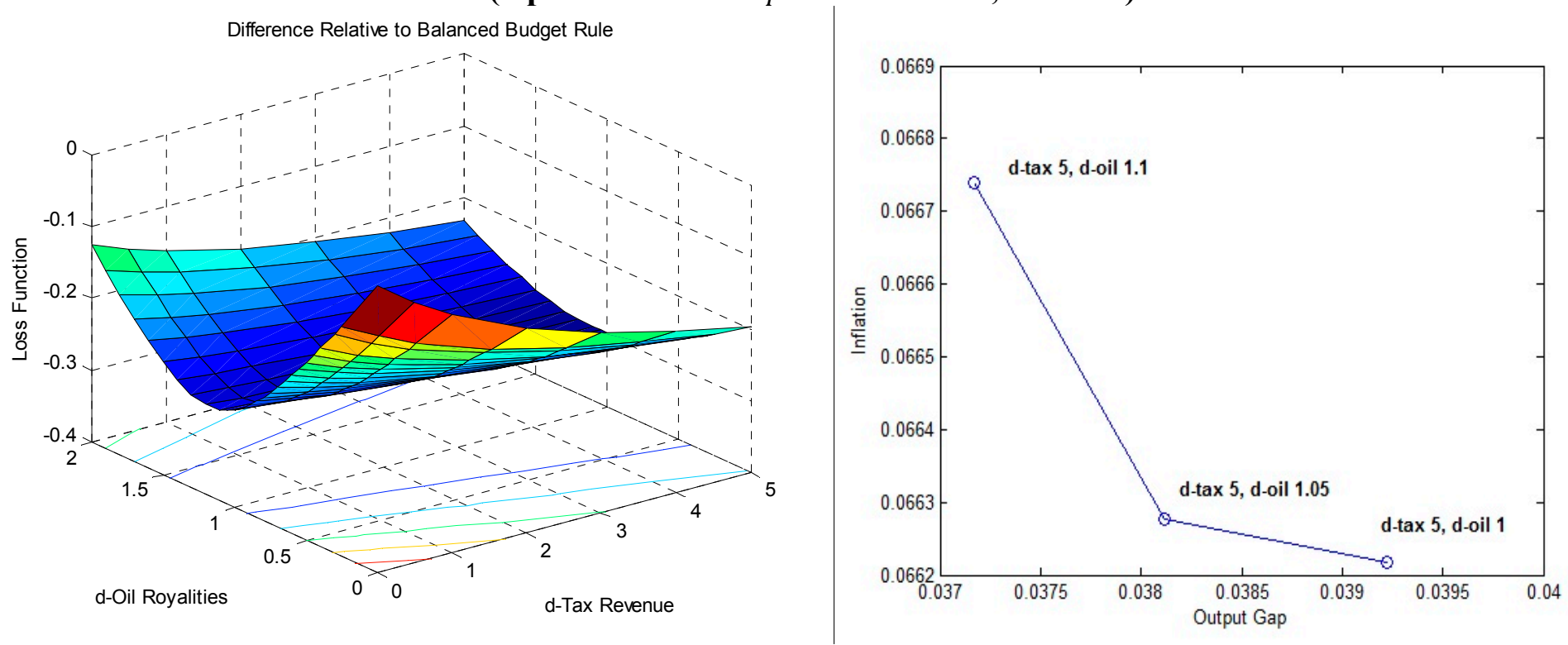


\section{Figure 7: Temporary Reduction in Oil Supply in the Rest of the World, Effects on the SOE: Fixed Exchange Rates ( $x$-axis in years)}

Inflation Target SSR

... Inflation Target CCR (d-oil 1.2, d-tax 5)
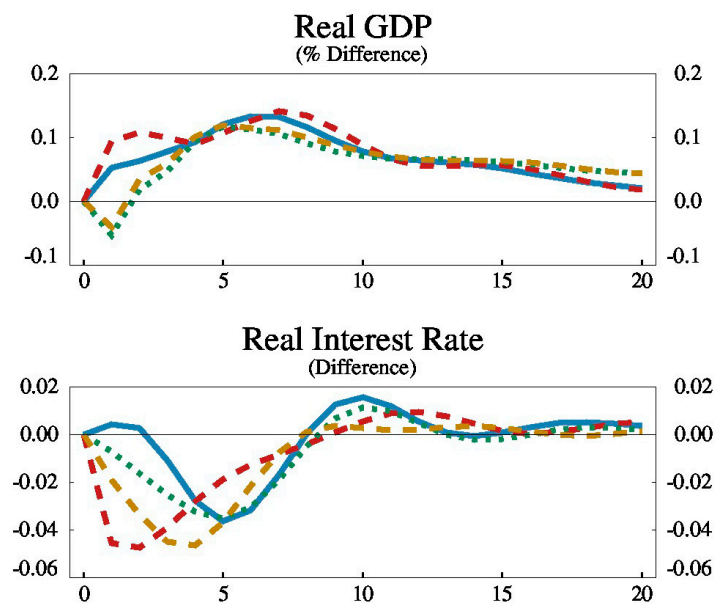

Tax Revenue Gap

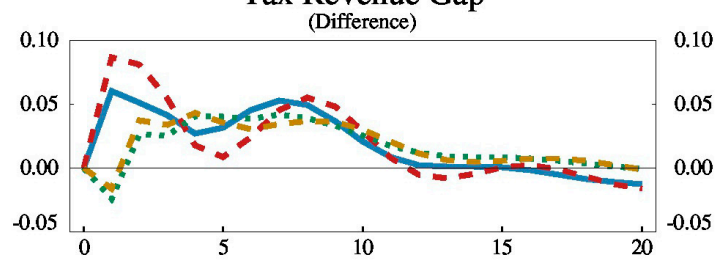

Tax Revenue/GDP

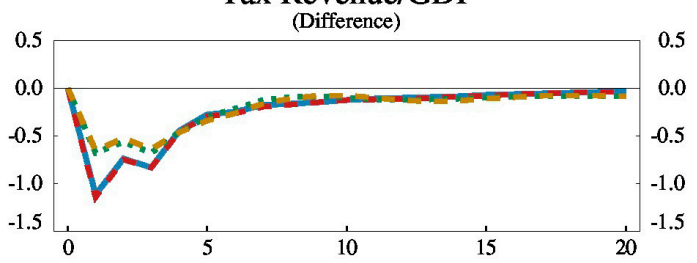

Government Deficit/GDP

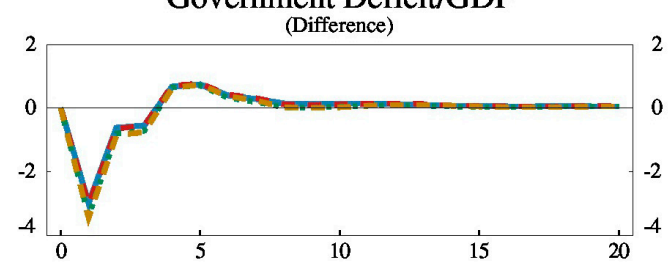

Real Bilateral Exchange Rate

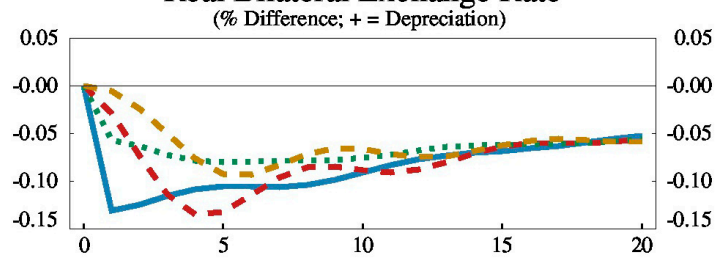

Fixed Exchange Rate SSR

Fixed Exchange Rate CCR (d-oil 1.2, d-tax 5)

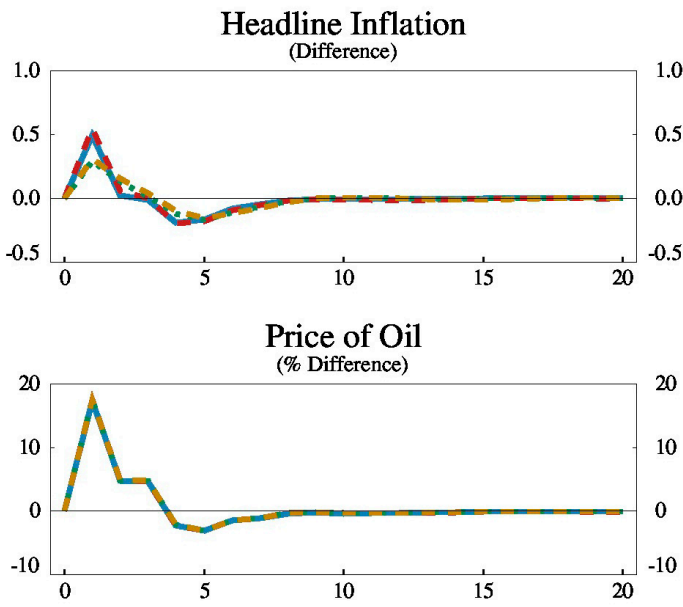

Commodity Royalities Gap

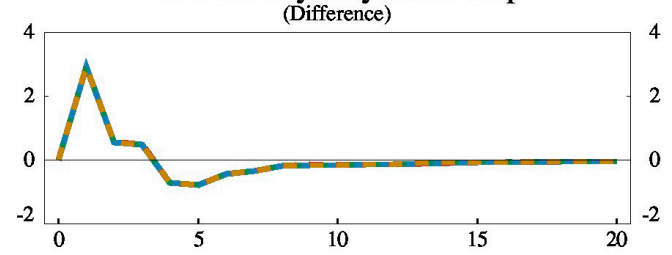

Labor Tax Rate

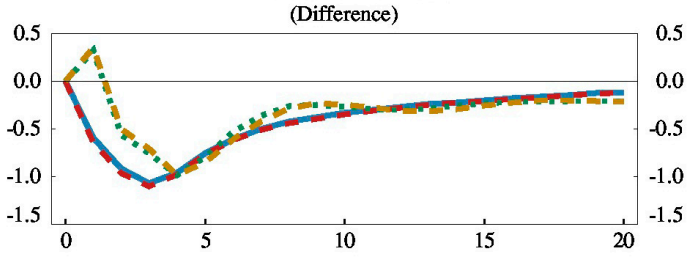

Domestic Gov't Debt/GDP

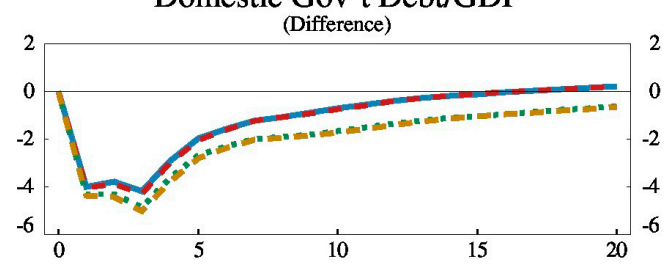

Current Account/GDP

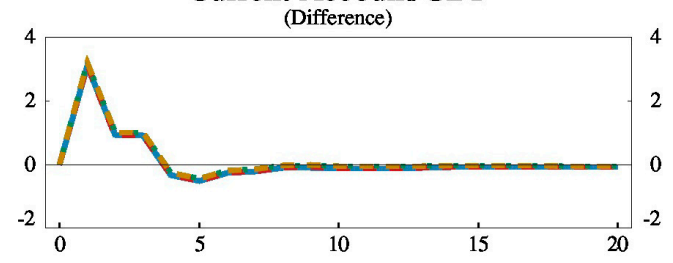




\section{Figure 8: Temporary Increase in Liquidity in the Rest of the World, Effects on the SOE: Fixed Exchange Rates (x-axis in years)}

Inflation Target SSR

... Inflation Target CCR (d-oil 1.1, d-tax 5)

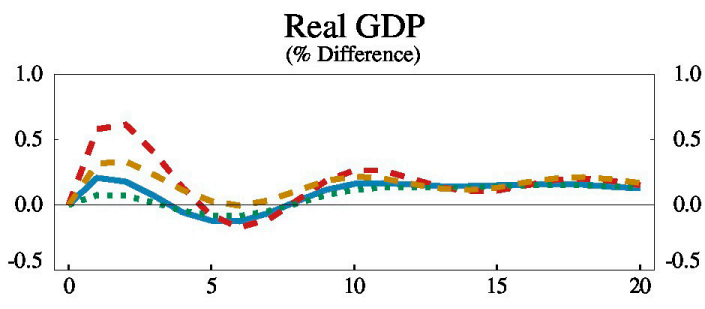

Real Interest Rate

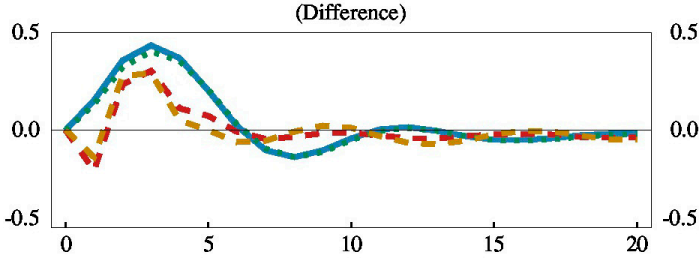

Tax Revenue Gap

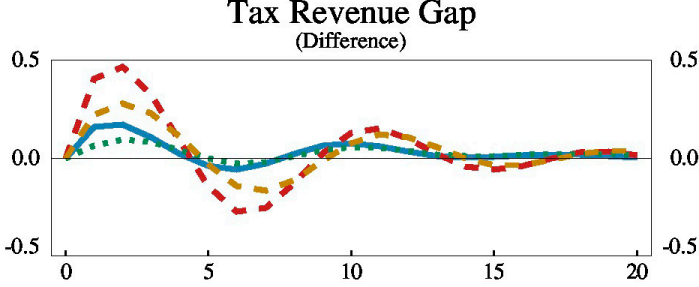

Tax Revenue/GDP

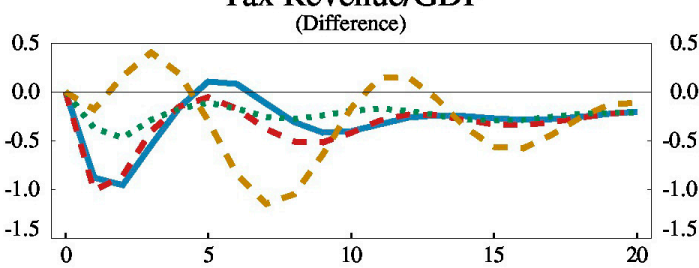

Government Deficit/GDP

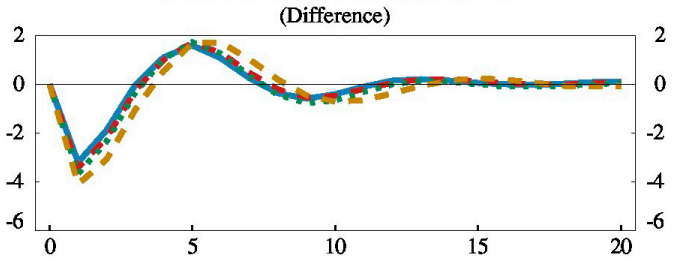

Real Bilateral Exchange Rate

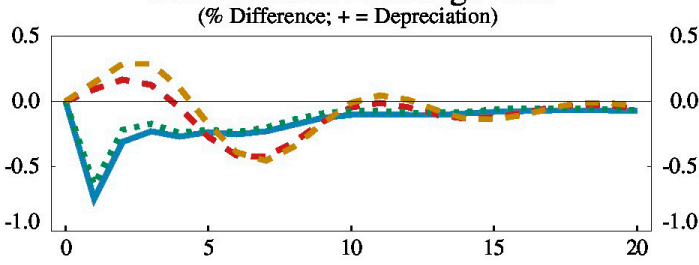

Fixed Exchange Rate SSR Fixed Exchange Rate CCR (d-oil 1, d-tax 5)

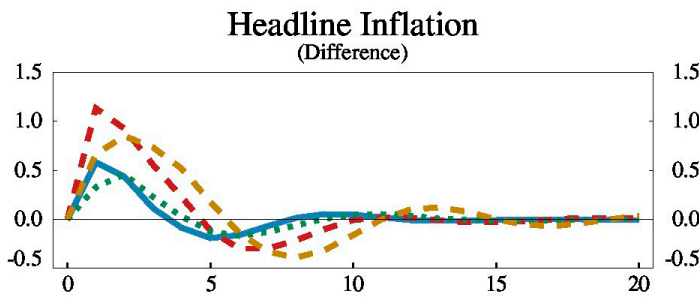

Price of Oil

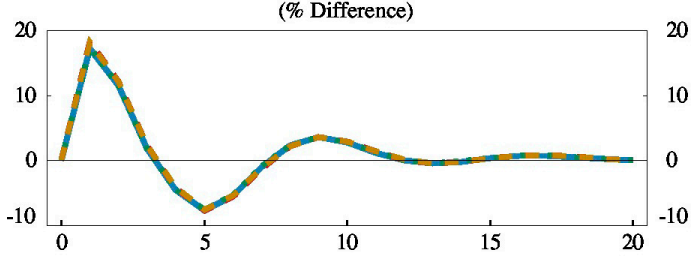

Commodity Royalities Gap (Difference)

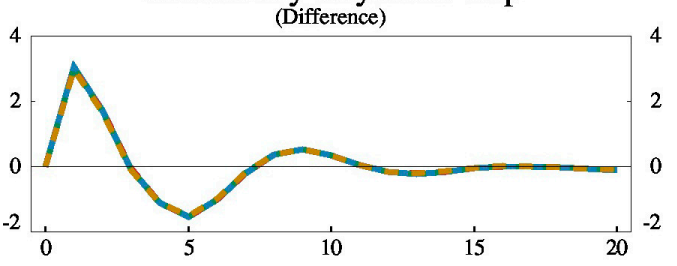

Labor Tax Rate

(Difference)

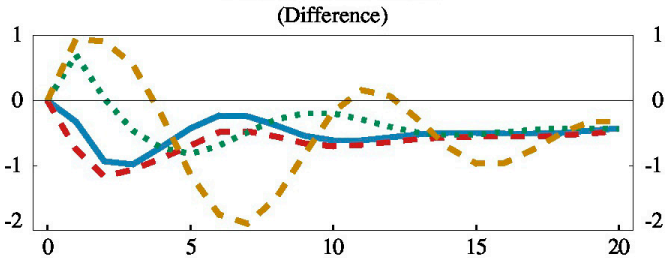

Domestic Gov't Debt/GDP

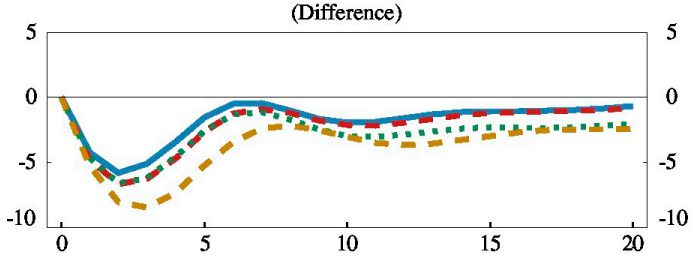

Current Account/GDP

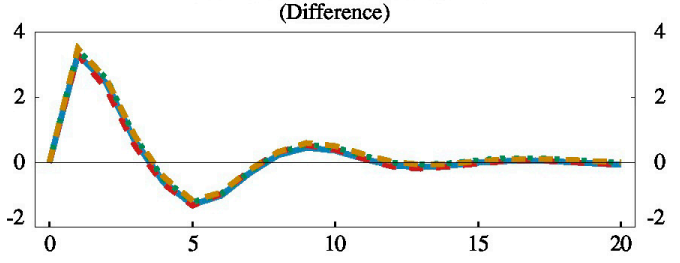


Figure 9 and 9.A: Temporary Reduction in Oil Supply in the Rest of the World, Evaluated Loss Function and Policy Efficiency Frontier: Fixed Exchange Rates

(Optimal Rule at $\lambda_{Y}=1: d^{\text {oil }}=1.2, d^{\text {tax }}=5$ )
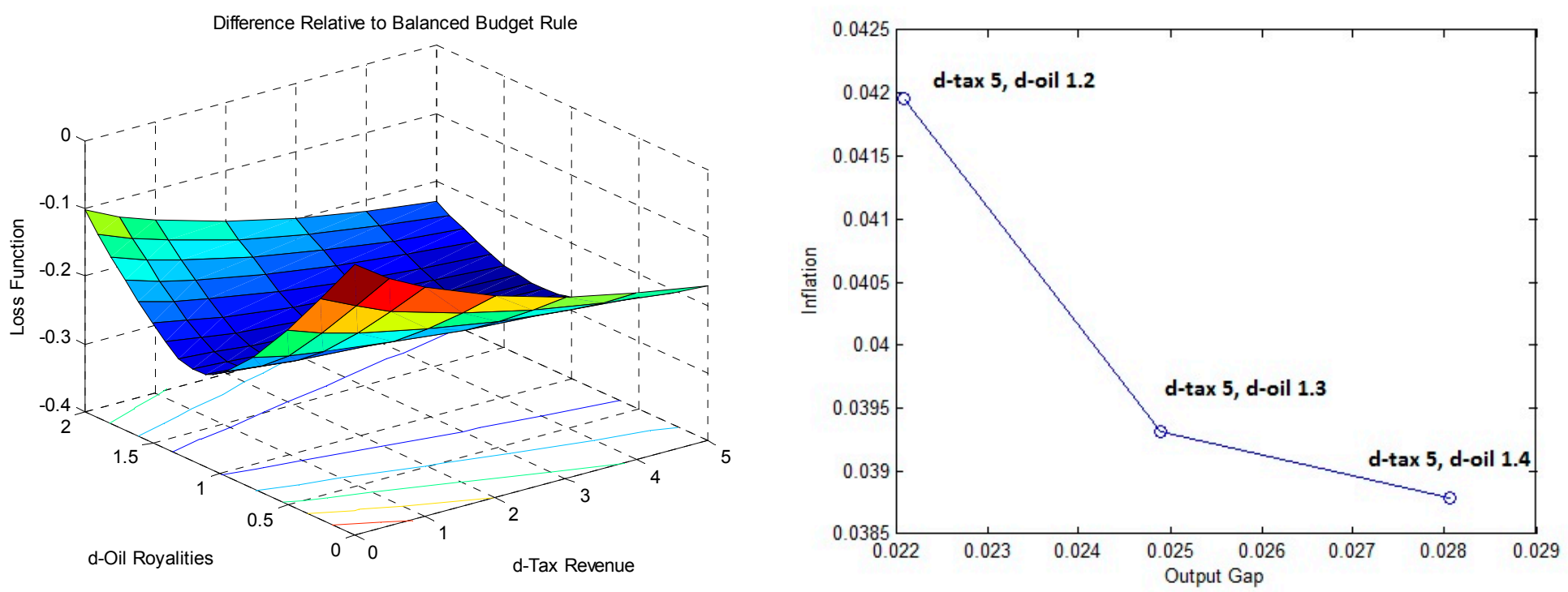

Figure 10 and 10.A: Temporary Increase in Liquidity in the Rest of the World, Evaluated Loss Function and Policy Efficiency Frontier: Fixed FX Rate (Optimal Rule at $\lambda_{Y}=1: d^{\text {oil }}=1, d^{\text {tax }}=5$ )
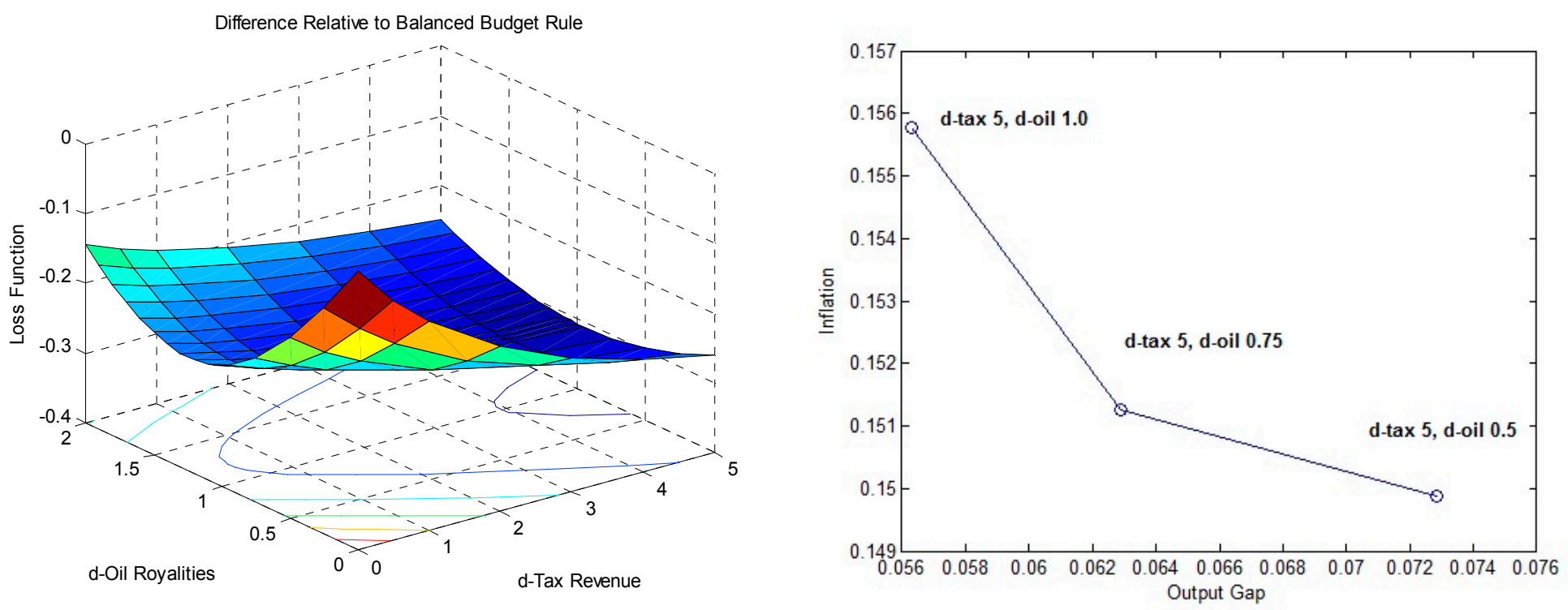


\section{Technical Appendix}

This appendix focuses on the oil sector which has been slightly modified from the oil sector in technical description of Kumhof and others (2010). All other structural foundations of the model are true to Kumhof and others (2010). The oil sector is characterized by a low price elasticity of supply and for analytical tractability is modeled by an exogenous endowment of oil flow, $X_{t}^{\text {exog }}$, in each period for each country. This oil flow grows at growth rate, $T_{t} n^{t}$, and can be stored and drawn from a stockpile, $\mathrm{O}_{\mathrm{t}}$, which exists primarily for computational reasons to act as an escape valve for real adjustment costs. This feature is not central to the dynamics of the model and is calibrated so that there is almost no oil storage in the dynamics but so that the real adjustment costs do not cause computational problems. Specifically the cost of storage is given by:

$$
G_{t}^{O}=\frac{\phi_{O}}{2\left(T_{t} n^{t}\right)} O_{t}^{2}-\kappa_{O} O_{t}
$$

where $G_{t}^{O}$ is the cost of storage, $\mathrm{T}_{\mathrm{t}}$ is the productivity growth rate, $\mathrm{n}^{\mathrm{t}}$ is the population growth rate, $\phi_{O}$ and $\kappa_{O}$ are parameters determining the cost of storage. The raw material producer's optimization problem is given by:

$$
\max _{\left\{O_{t+s}\right\}_{s=0}^{\infty}} E_{t} \sum_{s=1}^{\infty} \bar{R}_{t, s} P_{t+s}^{X}\left(X_{t+s}^{\text {exog }}-\left(O_{t+s}-O_{t+s-1}\right)-G_{t+s}^{o}\right), O_{t}
$$

where $P_{t}^{X}$ is the nominal market price of crude oil, and $\bar{R}_{t}$ is the steady-state real interest rate. The first order condition is:

$$
1-\kappa_{O}+\phi_{O} \check{O}_{t}=E_{t} \frac{\theta}{\check{r}_{t}} \frac{p_{t+1}^{X}}{p_{t}^{X}}
$$

where, $\theta$, is the probability of survival of OLG agents, $\check{O}_{t}$ is real oil supply where $\check{O}_{t}=O_{t} / T_{t} n^{t}$, and $\breve{\mathrm{r}}_{\mathrm{t}}$ is the real interest rate payable by the private sector. The real supply of crude oil, $\breve{X}_{t}^{\text {sup }}$, is given by:

$$
\check{X}_{t}^{\text {sup }},=\check{X}_{t}^{\text {exog }}-\left(\check{O}_{t}-\frac{\check{o}_{t-1}}{g n}\right)-\check{G}_{t}^{O}
$$

The exogenous oil supply, $\breve{X}_{t}^{\text {exog }}$, is subject to shocks to domestic supply, $e_{t}^{X}$. The size of the endowment has a small positive elasticity, $\varepsilon^{X}$, to the ten-year, backward-looking moving average of the oil price with a five-year lag:

$$
\log \left(\check{X}_{t}^{\text {exog }}\right)=\rho^{X} \log \left(\check{X}_{t-1}^{\text {exog }}\right)+\log \left(\bar{X}^{\text {exog }}\right)+\varepsilon^{X} \log \left(p_{t-5}^{x_{\text {ave }}} / \bar{p}^{x}\right)+e_{t}^{X}
$$


where $\rho^{X}$ is the AR(1) coefficient of shock persistence, and $\bar{p}^{x}$ is the steady-state price of crude oil. The elasticity of oil supply, $\varepsilon^{X}$, is 0.03 to permanent oil price increases and takes 15 years to fully effect the flow of oil supply.

The total demand of crude oil in each country is given by $\check{X}_{t}^{d e m}$, and is the sum of the demand for oil in production in the tradable goods, $\breve{X}_{t}^{T}$, non-tradables goods, $\check{X}_{t}^{N}$, and via direct household consumption, $\check{X}_{t}^{C}$ :

$$
\check{X}_{t}^{d e m}=\check{X}_{t}^{T}+\check{X}_{t}^{N}+\check{X}_{t}^{C}
$$

The normalized value of each country's net crude oil exports is given by:

$$
\check{X}_{t}^{x}=p_{t}^{x}\left(\check{X}_{t}^{\text {sup }}-\check{X}_{t}^{\text {dem }}\right)
$$

The supply of crude oil is sold into a global market which is perfectly competitaive with a single global market price of crude oil. Oil rents are the difference between the extraction cost and the market price of oil and may accrue to households, the government, or foreign households. A constant share of normalized steady-state crude oil revenue, $s_{f}^{x}$, is paid to domestic OLG agents as a dividend, $\check{d}_{t}^{X}$, given by:

$$
\check{d}_{t}^{X}=s_{d}^{x} \check{p}_{t}^{X} \check{X}_{t}^{\text {sup }}
$$

The remaining profits, $\left(1-s_{d}^{x}\right) p_{t}^{X} \breve{X}_{t}^{s u p}$, are distributed by constant share, $s_{f}^{x}$, via dividends to the foreign OLG agents in the ROW, $\check{f}_{t}^{x}$, and to payments to the government $\check{g}_{t}^{x}$, where:

$$
\begin{aligned}
\check{f}_{t}^{x} & =s_{f}^{x}\left(p_{t}^{X} \check{X}_{t}^{\text {sup }}-\check{d}_{t}^{X}\right), \text { and } \\
\check{g}_{t}^{x} & =p_{t}^{X} \check{X}_{t}^{\text {sup }}-\check{d}_{t}^{X}-\check{f}_{t}^{x} .
\end{aligned}
$$

By international arbritrage the domestic price of oil is given by:

$$
p_{t, j}^{X}=p_{t}^{X} e_{t}
$$

where $e_{t}$ is the nominal bilaterial exhange rate against the ROW. Similarly, the dividends received by the rest of the world for ownership of the SOE oil production are given by:

$$
\check{d}_{t, R O W}^{x}=\check{f}_{t, S O E}^{x} / e_{t}
$$

The market-clearing condition for the crude oil market world wide is given by:

$$
\sum_{j=1}^{N}\left(\check{X}_{t}^{\text {sup }(j)}-\check{X}_{t}^{\text {dem }(j)}\right)=0 .
$$


VIII. APPEndix Of THE Calibration

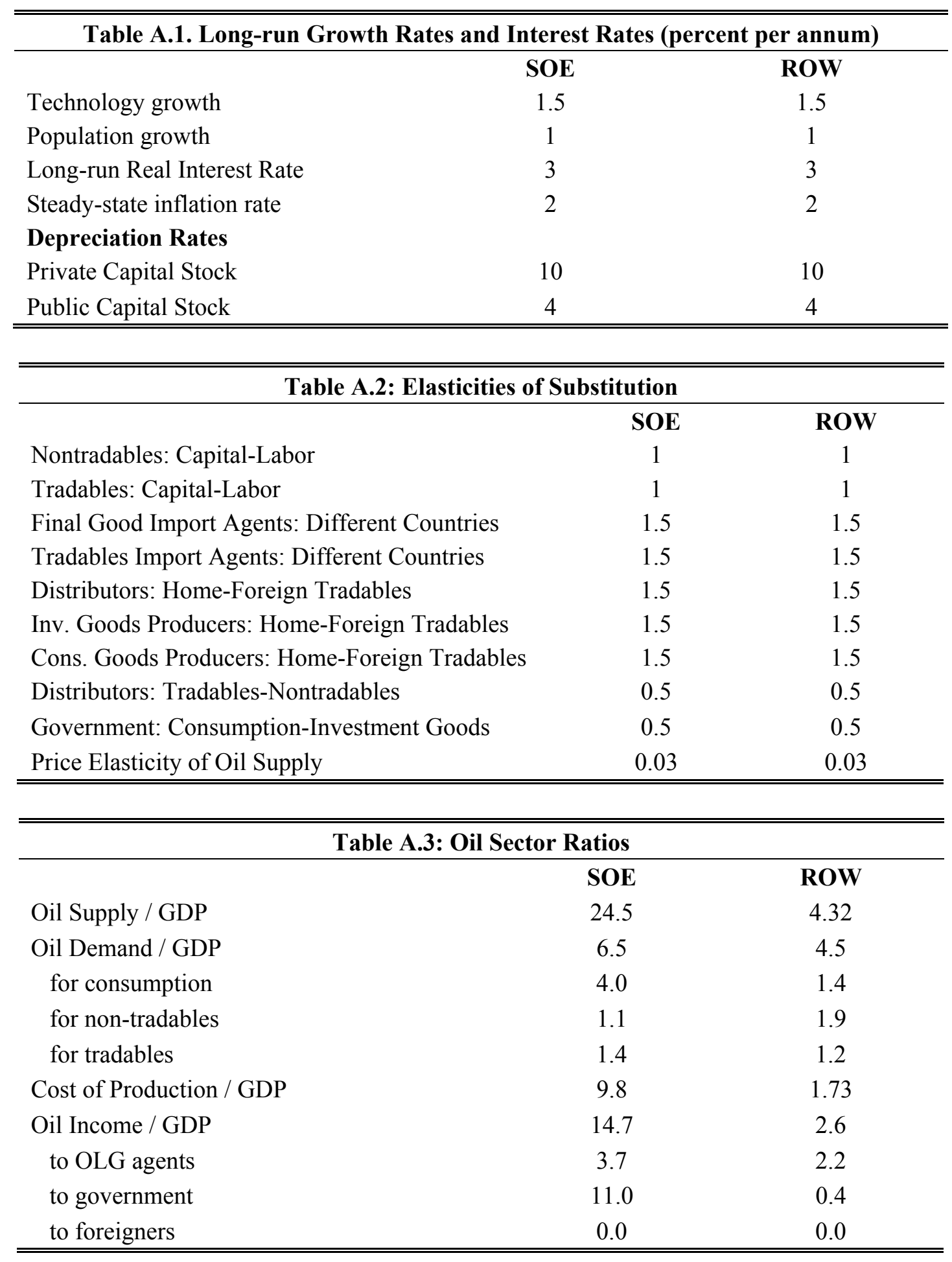




\begin{tabular}{lcc}
\hline \hline \multicolumn{3}{c}{ Table A.4: Steady-state Factor Shares } \\
\hline & SOE & ROW \\
Nontradables Labor Income / GDP & 60 & 60 \\
Tradables Labor Income / GDP & 66 & 66 \\
Nontradables Output / Manufacturing Output & 50 & 50 \\
Consumption Goods Input / Government Output & 50 & 50 \\
\hline \hline
\end{tabular}

Table A.5: Utility Functions

\begin{tabular}{lcc}
\hline & SOE & ROW \\
Average Planning Horizon in Years & 10 & 10 \\
Average Remaining Working Life & 20 & 20 \\
Intertemporal Elasticity of Substitution & 0.25 & 0.25 \\
Labor Supply Elasticity & 0.5 & 0.5 \\
Share of Liquidity-constrained Agents & 0.5 & 0.3 \\
Dividend Share of Liq. Constrained Agents & 0 & 0 \\
\hline \hline
\end{tabular}

Table A.6. Steady-state GDP Ratios

\begin{tabular}{lcc}
\hline & SOE & ROW \\
\hline Share in World GDP & $\mathbf{1 . 1}$ & $\mathbf{9 8 . 9}$ \\
\hline National Accounts & & \\
Consumption / GDP & 60.0 & 61.5 \\
Private Investment / GDP & 20.0 & 19.0 \\
Government Investment / GDP & 3.0 & 2.5 \\
Government Consumption / GDP & 17.0 & 17.0 \\
Exports / GDP & $\mathbf{4 0 . 0}$ & - \\
Final Goods Exports / GDP & 12.0 & - \\
Intermediate Goods Exports / GDP & 10.0 & - \\
Net Oil Exports / GDP & 18.0 & - \\
Imports / GDP & $\mathbf{4 0 . 0}$ & - \\
Consumption Goods Imports / GDP & 20.0 & - \\
Investment Goods Imports / GDP & 12.0 & - \\
Intermediate Goods Imports / GDP & 8.0 & - \\
Fiscal Accounts & & \\
Government Debt / GDP & 30 & 60 \\
Labor Tax Revenue / GDP & 15.5 & 15.5 \\
Capital Tax Revenue / GDP & 3.0 & 3.0 \\
Consumption Tax Revenue / GDP & 7.5 & 7.5 \\
\hline \hline
\end{tabular}


Table A.7: Financial Accelerator Sector

\begin{tabular}{lcc}
\hline \multicolumn{3}{c}{ Table A.7: Financial Accelerator Sector } \\
& SOE & ROW \\
Leverage in Nontradables in \% & 100 & 100 \\
Leverage in Tradables in \% & 100 & 100 \\
Annual Bankruptcy Rate in Nontradables in \% & 8 & 8 \\
Annual Bankruptcy Rate in Tradables in \% & 8 & 8 \\
External Finance Premium in Nontradables in \% & 2.5 & 2.5 \\
External Finance Premium in Tradables in \% & 2.5 & 2.5 \\
\hline \hline
\end{tabular}

Table A.8: Monetary and Fiscal Rule Parameters

\begin{tabular}{lcc}
\hline & SOE & ROW \\
Monetary-policy Reaction Function & & \\
Lagged Nominal Interest Rate, $\delta_{t}$ & 0.3 & 0.3 \\
Inflation, $\delta_{\pi}$ & 1.5 & 1.0 \\
Inflation target, $\bar{\pi}$ & 2 & 2 \\
Lead on inflation (in quarters) & 3 & 3 \\
Fiscal Rule Parameters & & \\
Change in deficit to output gap, $d^{g d p}$ & - & 0.0 \\
\hline \hline
\end{tabular}

Table A.9: Adjustment Costs

SOE ROW

Price Adjustment Costs

Unions 40

$\begin{array}{ll}40 & 40 \\ 40 & 40 \\ 40 & 40 \\ 40 & 40 \\ 30 & 30 \\ 30 & 30\end{array}$

Distributors

40

Non Tradable Sector

40

Tradable Sector

40

Imported Final Goods

30
30

Imports Intermediary Goods

22

Consumption

$\begin{array}{ll}2 & 1 \\ 1 & 1\end{array}$

Labor Demand

Trade Flows of Final Goods

Trade Flows of Intermediary Goods

$1-1$

Oil in Non-tradables Production

$1-1$

Oil in Tradables Production

$25 \quad 25$

Oil in Consumption

25

25

Stock of Reserves of Refined Oil

25

25

100000

100000 